\begin{tabular}{|c|c|c|c|}
\hline Article Info & RESEARC ARTICLE & ARAŞTIRMA MAKALESI & \\
\hline Title of Article & \multicolumn{2}{|c|}{$\begin{array}{c}\text { Human Centred Design Approach Within the } \\
\text { Framework of the Search for Quality in Urban } \\
\text { Spaces: The Case of Edirne Selimiye Mosque and Its } \\
\text { Vicinity }\end{array}$} & \\
\hline $\begin{array}{l}\text { Corresponding } \\
\text { Author }\end{array}$ & \multicolumn{2}{|c|}{$\begin{array}{l}\text { Tuğba KİPER/ Tekirdağ Namık Kemal Üniversitesi Güzel Sanatlar, Tasarım ve Mimarlık } \\
\text { Fakültesi Peyzaj Mimarlığı Bölümü, tkiper@ @ku.edu.tr }\end{array}$} & \\
\hline $\begin{array}{l}\text { Received Date } \\
\text { Accepted Date }\end{array}$ & \multicolumn{2}{|l|}{$\begin{array}{l}28.11 .2020 \\
09.03 .2021 \\
\end{array}$} & \\
\hline Author / Authors & $\begin{array}{l}\text { Ayça NEĞIŞ } \\
\text { Tuğba KİPER } \\
\text { Murat ÖZYAVUZ }\end{array}$ & $\begin{array}{l}\text { ORCID: 0000-0003-3263-6890 } \\
\text { ORCID: 0000-0003-3396-5661 } \\
\text { ORCID: 0000-0003-3418-9713 }\end{array}$ & \\
\hline How to Cite & \multicolumn{2}{|c|}{$\begin{array}{l}\text { NEĞIŞ, A., KİPER, T., ÖZYAVUZ, M.. (2021). Kentsel Mekanlarda Kalite Arayışı } \\
\text { Çerçevesinde İnsan Odaklı Tasarım Yaklaşımı: Edirne Selimiye Camii ve Çevresi } \\
\text { Ôrneği, Kent Akademisi, Volume, } 13 \text { (43), }\end{array}$} & $\begin{array}{l}\text { Kent Akademisi } \\
\text { Urbarn Academy }\end{array}$ \\
\hline
\end{tabular}

\title{
Kentsel Mekanlarda Kalite Arayışı Çerçevesinde İnsan Odaklı Tasarım Yaklaşımı: Edirne Selimiye Camii ve Çevresi Örneği
}

\author{
Ayça NEĞíș ${ }^{1}$ \\ Tuğba KİPER ${ }^{2}$ \\ Murat ÖZYAVUZ ${ }^{2}$
}

\begin{abstract}
:
Many strategies with the themes of livability and sustainability have been developed in solving environmental problems arising with rapid urbanization. At the basis of the strategies developed, nature and human priority quality quests have taken place and concepts such as quality of life and space quality have come to the fore. In this context, the study is built on the hypothesis that "Spatial quality is an importantf actor in the development of design decisions for urban out door spaces". For this purpose, design decisions for the physical space quality of Edirne Province Selimiye Mosque and its vicinity have been developed. In line with the study, comfort-image oriented spatial quality arameters were developed within the framework of literature information and field observations. Maps regarding transportation conditions, building-function conditions, green area conditions, mass space, floor heights, urban images, protected areas and registered building conditions were created in accordance to the specified parameters. As a result of the study, the strengths and weaknesses of the area were determined and various design decisions were developed for the application to improve the quality of the space within the scope of the findings obtained from the analyzes.
\end{abstract}

KEYWORDS: Urban Space, Spatial Quality, Urban Space Quality, Comfort and Image, Edirne Selimiye Mosque

\section{ÖZ:}

Hızlı kentleşme ile ortaya çıkan çevresel sorunların çözümünde yaşanılabilirlik, sürdürülebilirlik temalı birçok strateji geliştirilmiştir. Geliştirilen stratejilerin temelinde de doğa ve insan öncelikli kalite arayışları yer almış olup, yaşam kalitesi, mekan kalitesi gibi kavramlar ön plana çıkmıştır. Bu kapsamda çalışma "Kentsel dış mekanlara yönelik

\footnotetext{
${ }^{1}$ Tekirdağ Namık Kemal Üniversitesi, Fen Bilimleri Enstitüsü, Peyzaj Mimarlığı Anabilim Dalı Yüksek Lisans Öğrencisi, aycanegis@gmail.com.

2 Tekirdağ Namık Kemal Üniversitesi, Güzel sanatlar, Tasarım ve Mimarlık Fakültesi, Peyzaj Mimarlığı Bölümü, Tekirdağ, tkiper@nku.edu.tr, mozyavuz@nku.edu.tr.
} 
tasarım kararlarının geliştirilmesinde, mekan kalitesi önemli bir etkendir” hipotezi üzerine kurgulanmıştır. Bu amaçla; Edirne İli Selimiye Camii ve yakın çevresinin fiziksel mekan kalitesine yönelik tasarım kararları geliştirilmiştir. Çalışma doğrultusunda; literatür bilgileri ve arazi gözlemleri çerçevesinde konfor-imaj odaklı mekansal kalite parametreleri geliştirilmiştir. Belirlenen parametreler doğrultusunda; ulaşım durumu, yapi-fonksiyon durumu, yeşil alan durumu, kütle boşluk durumu, kat yükseklikleri, kentsel imgeler, korunan alanlar ve tescilli yapı durumuna ilişkin haritalar oluşturulmuştur. Çalışma sonucunda; analizlerden elde edilen bulgular kapsamında alana ilişkin güçlü ve zayıf yönler saptanarak, mekan kalitesini geliştirecek uygulamaya yönelik çeşitli tasarım kararları geliştirilmiştir.

ANAHTAR KELIMELER: Kentsel Mekan, Mekan Kalitesi, Kentsel Mekan Kalitesi, Konfor ve İmaj, Edirne İli Selimiye Camii

\section{“Kentsel Mekanlarda Kalite Arayışı Çerçevesinde İnsan Odakı Tasarım Yaklaşımı: Edirne Selimiye Camii ve Çevresi Örneği”’}

\section{GíRiş}

Kent, topluluk olarak yaşayan insanların, ortak yaşamlarından doğan ve onların yaşam biçimleri ile şekillenen (Kaya, 2007), arazi kullanımının ve insan etkisinin en fazla olduğu alanlardır. Bununla birlikte kentler; doğal, fiziksel, sosyal ve ekonomik özelliklerin birlikteliği ile şekillenen dinamik bir yerleşim alanıdır. Sahip olduğu bu özellikleri ile süreç içerisinde kentsel alanlarda çeşitli değişim ve dönüşümler yaşanmıştır. Bu da kentsel alanların planlanması ve tasarımına yönelik çeşitli yaklaşımların geliştirilmesine sebebiyet vermiştir. Ülkemizde Onuncu ve Onbirinci Kalkınma Planları ile kentlere ilişkin karar alma süreçlerinde "kentsel yaşam kalitesi" yaklaşımının geliştirilmesi de bunun bir örneğidir. Bu kapsamda kentsel alanlarda "kalite" kavramı üzerinde önemle durulan bir konu haline gelmiştir. Beardsley (1998); kalite için, "işlevsel açıdan etkin, yapısal açıdan sağlam ve görsel açıdan çekici" kavramlarını tanımlamıştır. Kentlerin önemli bir parçası olan kentsel mekanlar, kentsel dokunun yapılaşmamış alanları, binalar dıșında kalan bölümleridir (Şahin ve Dostoğlu, 2007). İnceoğlu ve Aytuğ (2009)'un da belirttiği gibi; kentsel mekan, bir şehrin/kentin ana bütünleşme aracıdır. Bununla birlikte, salt kentsel mekanların varlığı yeterli değildir. Bu çerçevede, kentsel mekanların kalite parametreleri çerçevesinde nitelikli yaşam olanakları sunmalarına yönelik olarak tasarlanması gerekir. Bu noktada; kentsel mekan olarak tanımlanan sokaklar, binalar, yeşil alanlar, caddeler ve meydanlar gibi yapılar arasında yer alan alanların belirli bir kalite düzeyine erişebilmeleri için birtakım ölçütlere sahip olmaları gerekmektedir. Öyle ki Paumier (1988)'de; başarılı bir kamusal mekan tasarımında her ölçekte kalite kriterinin aranması gerektiğinden bahsetmiştir. Madden (2001) ve Whyte (2000) ise; kolay ulaşlabilirlik, konfor, sosyallik ve aktivitenin kamusal mekan kalitesinin dört ana karakterini oluşturduğundan bahsetmiştir. Bu noktada kentsel mekanların tasarımında insan ihtiyaçlarının temel noktada yer aldığı görülmüştür. Lynch (1990), Sherwin Greene (1992); Nasar (1998), Voordt ve Wegen (2005); Van der Voort ve Van Wegen (2005); PPS (2007); Gehl (2011)'in yapmış oldukları pek çok çalışmada da insan ihtiyaçlarına göre şekillenen mekan kalitesi üzerinde durulmuştur. Bu çalıșmaların birçoğunda; bir kamusal alanın başarılı olabilmesi için, ulaşılabilir olması, kullanım çeşitliliğine sahip olması, konforlu ve iyi bir imajının olması gerektiğine dikkat çekilmiştir. Van der Voordt ve Van Wegen (2005), mekanda kalite kavramını işlevsel, estetik, teknik ve ekonomik kalite olmak üzere 4 ana başlıkta ele almıştır. Ülkemizde, 2009 yılında gerçekleştirilen "Kentleşme Şûrası"nda; "Mekansal karakteri destekleyerek, kentsel imaj ve kimlik değerlerini ön plana çıkaran" tasarım kararlarına vurgu yapılmıştır. Çevre ve Şehircilik Bakanlığı tarafından hazırlanan Kentsel Tasarım Rehberlerinde de kentsel açık alanlara ilişkin olarak "mekansal kalitenin arttırıldığı tasarım ve planlama yaklaşımlarının oluşturulması" hedeflenmektedir. "Bütünleşik Kentsel Gelişme Stratejisi ve Eylem Planı (2010-2023)" nda da kentsel mekan kalitesinin önemine dikkat çekilmiştir. Bununla birlikte; İnceoğlu, M. (2007); İnceoğlu ve Aytuğ (2009); Çınar Altınçekiç ve ark., (2014); Uzgören ve Erdönmez, (2017); Acarlı ve ark, (2018); Akbaş ve Kiper (2020) gibi araştırmacılar da kentsel alanlarda mekan kalitesine yönelik çalışmalar yapmışlardır.

Buradan yola çıkılarak bu çalışmada; "Kentsel dış mekanlara yönelik tasarım kararlarının geliştirilmesinde, mekan kalitesi önemli bir etkendir" hipotezi çerçevesinde; Edirne İli Selimiye Camii ve yakın çevresinin fiziksel mekan kalitesine yönelik tasarım kararları geliştirilmiştir. Bu doğrultuda; literatür bilgileri ve arazi gözlemleri çerçevesinde mekansal kalite değerlendirilmesine yönelik çeşitli analizler (ulaşım yoğunluğu (taşıt, yaya, taşıt-yaya), kat yüksekliği, alan kullanımı, açık-yeşil alan, kütle-boşluk, kentsel imgeler, tescilli yapı durumu) yapılmıştır. Analizlerden elde edilen bulgular çerçevesinde alana ilişkin güçlü ve zayıf yönler saptanmış ve ulaşım, yeşil alan ile 
alan kullanımlarına yönelik malzeme, renk ve dokuya ilişkin uygulamaya dönük çeşitli tasarım kararları geliştirilmiştir.

\section{MATERYAL ve YÖNTEM}

\subsection{Materyal}

Çalışma alanı olarak, Edirne tarihi kent merkezinde bulunan Selimiye Camii ve çevresi seçilmiştir. Çalışma alanı yaklaşı $115000 \mathrm{~m}^{2}$ büyüklüğe sahip olup, alan içerisinde Edirne'nin simge yapıları arasında yer alan Selimiye Camii, Eski Camii, Üç Şerefeli Camii ve Bedesten yer almaktadır. Alan sınırları, Talat Paşa Caddesi, Kıyık Caddesi, Mimar Sinan Caddesi gibi üç ana arter ile çevrelenmektedir (Şekil 1).

M.Ö. 5. yüzyıldan günümüze kadar birçok farklı medeniyetin etkisi ile biçimlenmiş olan kent, M.Ö. 7. yüzyılda ilk kez Trak uygarlığına (Odrysia ya da Orestias), M.S. 123-124 y1llarında Roma İmparatoruna (Hadrianopolis) ve daha sonrada Bizans İmparatorluğuna ev sahipliği yapmıştır. Bizans döneminde surlarla çevrilen kare planlı kent suru, 1361 yılında Osmanlı tarafından fethedilmiş ve kente Edirne adını verilmiştir. Kent kalenin doğusunda gelişim göstererek, uzun yıllar Osmanlı İmparatorluğu'na başkentlik yapmıştır. Osmanlı mimarisinin izlerini taşıyan birçok kültür varlığı çalışma alanı ve çevresinde yer almaktadır. Bunlar; Eski Camii (1403-1414), Bedesten (1417-1418), Üç Şerefeli Camii (1443-1448), Kirazli (Hadım Şahabettin Paşa) Mescidi (1436), Selimiye Camii (1568-1575), Ali Paşa Çarşısı (1569), Peykler Medresesi ve Saatli Medrese (15.yy.), Rüstem Paşa Kervansarayı (16.yy.), Sokollu Mehmet Paşa Hamamı ve Taşhan (16.yy. 2. yarısı), Müşir Dairesi (Bugünkü Tümen Komutanlığı), Belediye Binası (1898), Dar-ül Eytam (Yetimler) Çarşısı (1911)'dır. Ayrıca deprem nedeniyle 1752 yılında yıkılmış, kazı ile kalıntıları bulunan Yemiş Kapanı Hanı da (1588) çalışma alanı içinde yer almaktadır (Usal, 2006; Erdoğan ve Kuter, 2010; Baysal, 2013; Karakaya, 2013; Ersoy, 2018; Anonim 2020a).

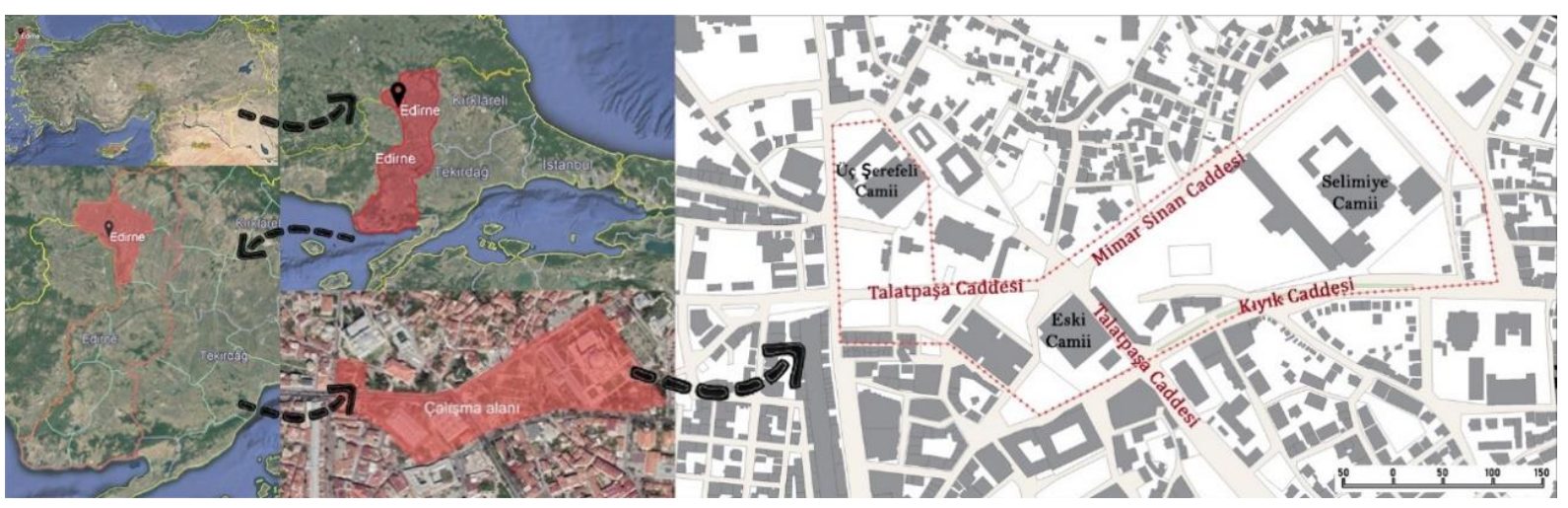

Şekil 1. Çalışma alanı konumu

Selimiye Camii ve çevresinin çalışma alanı seçilmesinin nedenleri aşağıda sıralanmıştır;

- Kentin simge yapılarının bulunması (Selimiye Camii, Eski Camii, Üç Şerefeli Camii),

- Ticari ve sosyal açıdan en önemli olan Saraçlar Caddesi, Yetimler Çarşısı ve Alipaşa Çarşısına yakın olması,

- Tarihi dokusu nedeni ile yerli ve yabancı turistlerin ilgi odağı olması,

- Alan çevresinde yaya kullanımın yoğun olması,

- Kentin önemli ulaşım bağlantılarının kesişim noktasında yer alması (Mimar Sinan Caddesi; Talatpaşa Caddesi ve Kiyık Caddesi),

- Alanın Kentsel Sit Alanı olarak koruma altına alınmış olması.

Çalışma alanı ve konusuyla ile ilgili makale, tez, rapor vb. literatür çalışmaları, alan özelinde ilgili kurum ve kuruluşlardan alınan veriler, arazi çalışmalarında yapılan yerinde gözlemler sonucu elde edilen veriler ile Edirne Belediyesi'ne ait 1/1000 ölçekli imar planı araştırmanın diğer materyallerini oluşturmaktadır.

\subsection{Yöntem}

Çalışma kapsamını, Selimiye Camii ve yakın çevresinin fiziksel mekan kalitesinin belirlenmesi oluşturmaktadır.

Çalışma metodu; (1) literatür araştırması ve veri toplama, (2) fiziksel mekan kalitesine yönelik çeşitli parametrelerin geliştirilmesi, (3) geliştirilen her bir parametreye ilişkin değerlendirmeler yapılarak çeşitli haritaların (ulaşım yoğunluğu (taşıt, yaya, taşıt-yaya), kat yüksekliği, alan kullanımı, açık-yeşil alan, kütle-boşluk, sit alanı sınırları ve kentsel imaj) oluşturulması, (4) haritalardan ve arazi gözlemlerinden elde edilen bilgiler kapsamında mevcut duruma 
ilişkin güçlü ve zayıf yönler ile firsat ve tehditlerin saptanması (SWOT Analizi), (5) ulaşım durumu, yeşil alan ve alan kullanımlarına yönelik malzeme, renk, doku özelinde uygulamaya yönelik çeşitli tasarım kararlarının geliştirilmesi olmak üzere 5 temel aşamada şekillenmiştir. Yöntem temel kurgusunun oluşturulmasında; Tırnakçı ve Aklıbaşında, 2018; Acarlı ve ark. 2019; Akbaş ve Kiper, 2020'in yapmış olduğu çalışmalar etken olmuştur.

Birinci aşamada; konu ve alan ile ilgili çeşitli literatür verileri toplanmış ve değerlendirilmiştir.

İkinci aşamada; örnek alanın fiziksel mekan kalitesine yönelik çeșitli parametreler oluşturulmuştur (Tablo 1). Parametrelerin saptanmasında, konu ile ilgili yurt içinde ve yurt dışında gerçekleştirilmiş araştırmalar ve incelemeleri içeren literatür taramaları (Lynch, 1990; Greene, 1992; Nasar, 1998; Türk, 2004; Franz, 2005; Voordt ve Wegen 2005; Voordt ve Wegen, 2005; Van der Voort ve Van Wegen, 2005; PPS, 2007; Gehl, 2011; İnceoğlu ve Aytuğ, 2009; Acarlı ve ark. 2019; Akbaş ve Kiper, 2020; Tırnakçı, 2020) etken olmuştur. Geliştirilen parametreler konfor ve imaj odaklı olarak 8 adet parametreden oluşmuştur.

Tablo 1. Fiziksel mekan kalite parametreleri (Lynch, 1990; Greene, 1992; Nasar, 1998; Türk, 2004; Franz, 2005; Voordt ve Wegen 2005; Voordt ve Wegen, 2005; Van der Voort ve Van Wegen, 2005; PPS, 2007; Gehl, 2011; İnceoğlu ve Aytuğ, 2009; Acarlı ve ark. 2019; Akbaş ve Kiper, 2020; Tırnakçı 2020' dan yararlanılarak oluşturulmuştur)

\begin{tabular}{|l|}
\hline Parametre \\
\hline Ulaşım Yoğunluğu (taşıt, yaya, taşıt-yaya) \\
\hline Mekanın Sunduğu Aktivite ve Fırsatlar (Yapı-fonksiyon durumu: ticaret, kültür, eğitim, konut, ibadet vb.) \\
\hline Yeşil Alan Durumu \\
\hline Kütle Boşluk Durumu \\
\hline İnsan Ölçüsüne Uygunluk (Kat yükseklikleri) \\
\hline Kentsel İmgeler (Bölge, düğüm, iz, landmark) \\
\hline Korunan Alanlar (Sit alanları) \\
\hline Tescilli Yapı Durumu (Tescilli sivil mimari yapı, anıtsal yapı) \\
\hline
\end{tabular}

Üçüncü aşamada; ulaşım yoğunluğu (taşıt, yaya, taşıt-yaya), kat yüksekliği, alan kullanımı, yeşil alan, kütle-boşluk durumu, kentsel imgeler, korunan alanlar ve tescilli yapılara ilişkin haritalar oluşturulmuştur. Haritalar mevcut durum ve Uygulama İmar Planlarına göre olmak üzere iki şekilde ele alınmıştır.

Dördüncü aşamada; haritalardan ve arazi gözlemlerinden elde edilen bilgiler kapsamında mevcut duruma ilişkin güçlü ve zayıf yönler ile firsat ve tehditler Swot Analizi tekniği çerçevesinde ortaya konmuştur.

Beşinci aşamada; elde edilen bulgular kapsamında ulaşım, tipoloji, malzeme, yeşil alan ile kentsel donatılara ilişkin, çeşitli görseller (plan, kesit, üç boyut görünümler) eşliğinde, mekansal kalitenin görsel ve işlevsel açıdan geliştirilmesi ile tarihi kent merkezinin sürdürülebilirliği için uygulamaya yönelik çeşitli tasarım kararları geliştirilmiştir.

\section{BULGULAR ve TARTIŞMA}

Çalışma alanı içerisinde yapılan gözlemler sonucunda; Selimiye Camii ve çevresinin yoğun olarak kullanıldığı gözlenmiştir. Birçok yaş grubundan yerli, yabancı turist ve yerel halk tarafından kullanılan; idari, ticari, dini ve eğitim alanları bulunmaktadır. Alan ve çevresinde tescilli yapıların bulunduğu ve bu yapıların işlevleri değiş̧irilerek veya aynen korunarak kullanılmaya devam edildiği belirlenmiştir. Bulgular kapsamında; Selimiye Camii ve çevresinde mevcut ve imar planı durumuna yönelik analizler yapılarak alanın zayıf ve güçlü yönleri belirlenmiştir.

\subsection{Ulaşım Durumuna İlişsin Bulgular}

Çalışma alanı çevresinde ulaşım durumu ile ilgili olarak mevcut ve Uygulama İmar Planına göre ulaşım ağı yoğunlukları saptanmıştır.

Yapılan gözlemler ve incelemeler doğrultusunda Talat Paşa, Kıyık, Hükümet ve Mimar Sinan Caddeleri 'nin araç ve yaya kullanımı olarak en yoğun kullanıma sahip caddeler olduğu belirlenmiştir (Şekil 2, Şekil 3). Bu caddelerin yoğun 
olarak kullanılmasının nedenleri; toplu taşıma güzergahlarında yer alması, turizm odaklarına yakın olması ve yaya öncelikli olarak kullanılan Saraçlar Caddesi ve Çilingirler Caddelerine yakın olmasıdır. Alan hem yaya hem de araç (özel, toplu taşım, vb.) ulaşımı açısından erişilebilir bir konumda yer almaktadır. Bununla birlikte çevresinde Landmark niteliğindeki anıtsal yapıların (Selimiye Cami, Üç Şerefeli Cami, Eski Cami) yer alması da araştırma alanının yoğun kullanımına neden olmaktadır. Bu da özellikle yoğun sirkülasyonla birlikte, ara sokakların otopark gibi kullanılmasını sağlamıştır. Bunun sonucu olarak da trafik akışında aksaklıklar ve düzensizlikler oluşmakta ve bu durum da araştırma alanının mekansal kalitesini düşürmektedir.

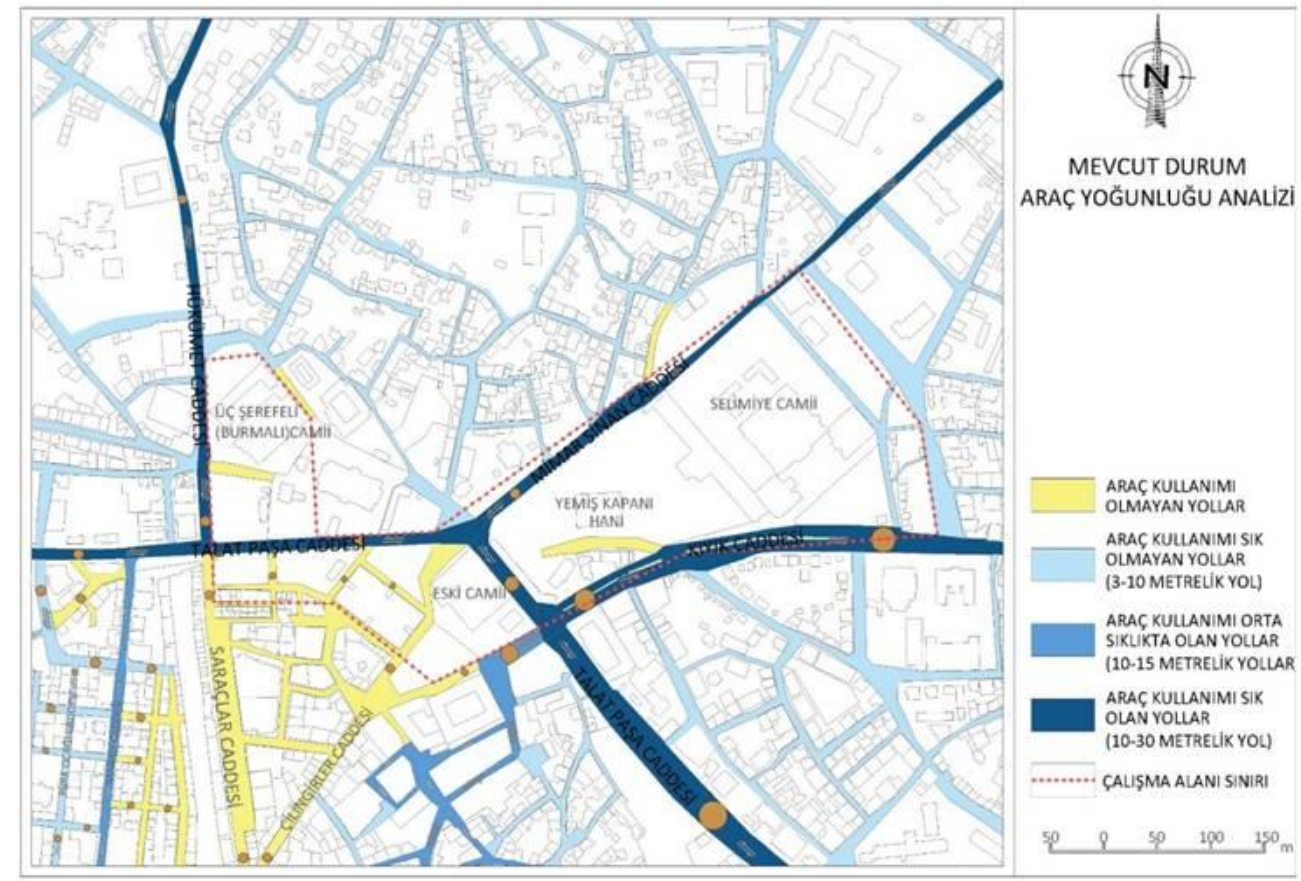

Şekil 2. Araştırma alanına ilişkin mevcut durum ulaşım yoğunluğu (taşıt, yaya, taşıt-yaya) analizi
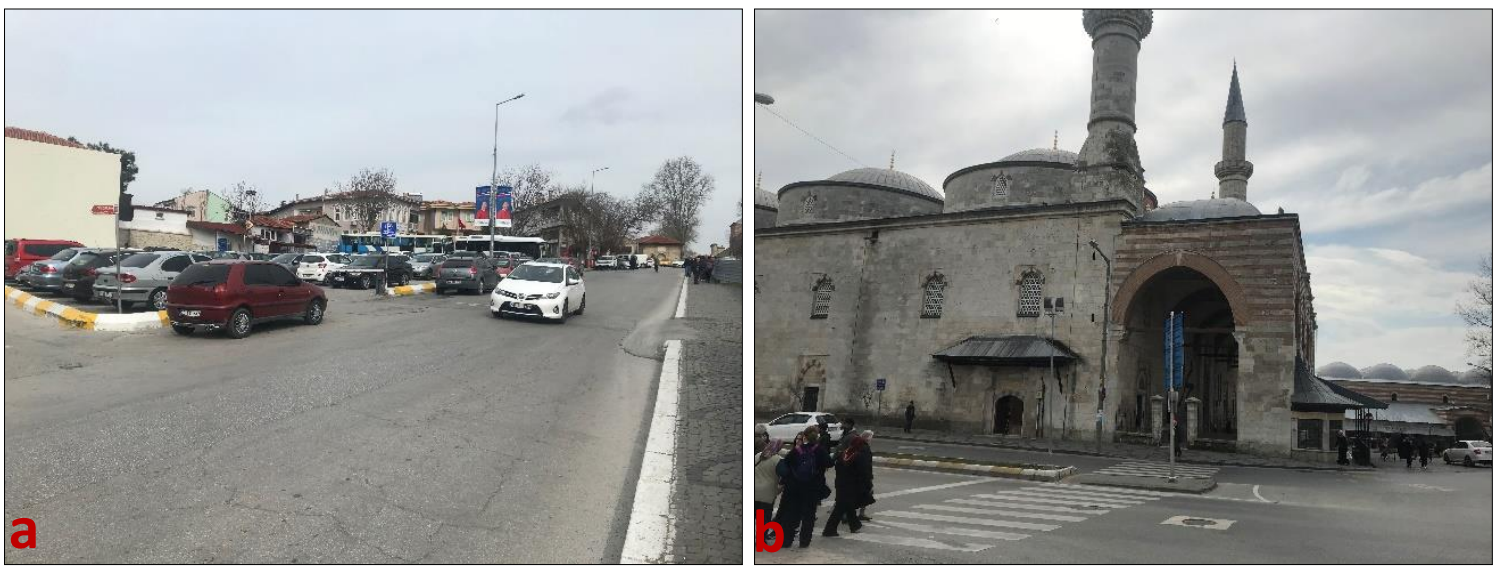

Şekil 3. a) Mimar Sinan Caddesi b) Talatpaşa Caddesi yaya geçidi

1/1000 ölçekli Uygulama İmar Planı'na göre; mevcutta yoğun araç kullanımı olan Talat Paşa Caddesi, Kıyık Caddesi, Hükümet Caddesi 17 ve 20 metre genişliğinde planlanmıştır. Alan genelinde trafik akışı çift yönlü iken 6 metre ve altı yollarda tek yönlü trafik akışı olduğu belirlenmiştir. Ayrıca araç trafiğine kapalı olan Çilingirler Caddesi ve Saraçlar Caddesi'nin çevresine ek olarak, Makedonya Kulesi çevresi de araç kullanımına kapatıldığı belirlenmiştir (Şekil 4). 


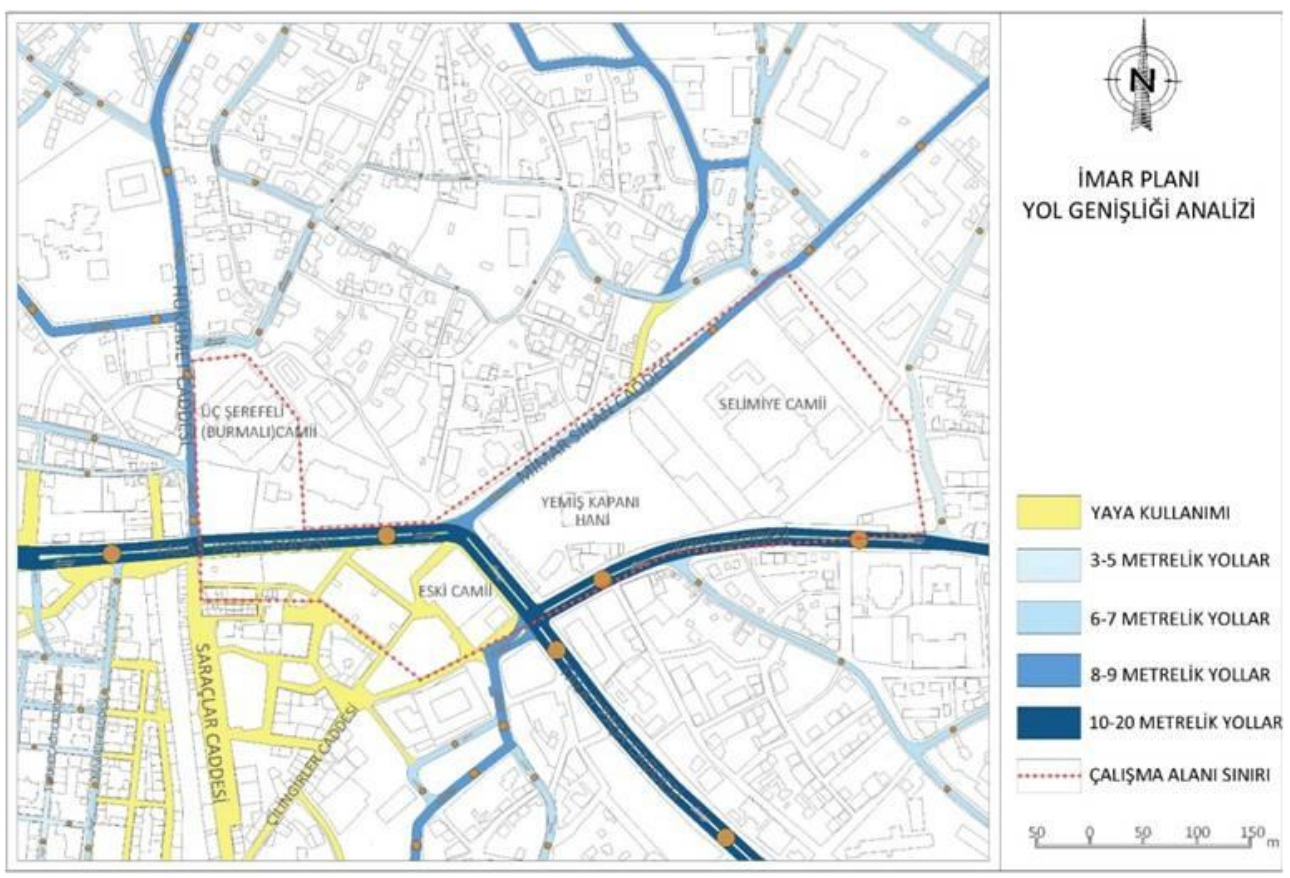

Şekil 4. Araştırma alanına ilişkin Uygulama İmar Planına göre yol durum analizi

\subsection{Alan Kullanımına İliş̧kin Bulgular}

$\mathrm{Bu}$ başlık çerçevesinde; çalışma alanı ve yakın çevresine ilişkin alan kullanımına ilişkin yapı-fonksiyon durum değerlendirmesi yapılmıştır. Çalışma alanı çevresinde yapıların \%49.4'ü konut, \%28.1'i ticari yapı, \%7.2'si kamu yapısı, \%6.5'i eğitim yapısı, \%7'si dini yapı, \%1.7'si askeri yapı olduğu belirlenmiştir. Çalışma alanı ve çevresinde çoğunlukla konut ve ticari yapılar bulunmaktadır. Ticari alanların bir noktada (Saraçlar ve Çilingirler Caddesinin çevresindeki) toplandığı ve ticaret odağı olduğu gözlenmiştir (Şekil 5).

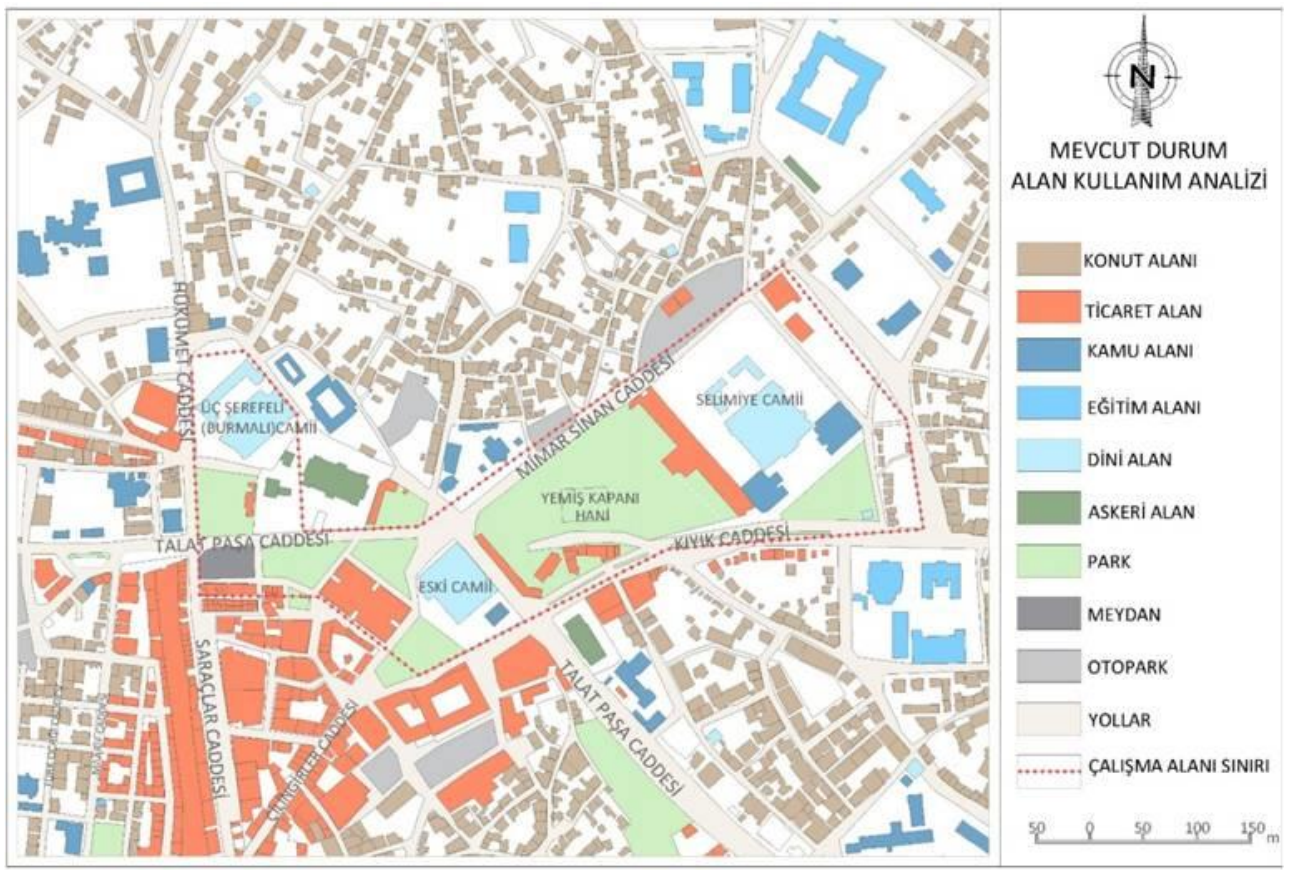

Şekil 5. Araştırma alanına ilişkin mevcut durum alan kullanım analizi 
Uygulama İmar Planına göre çalışma alanı çevresinde yapıların \%32.1'i konut, \%3.8'i ticari-konut, \%34.5'i ticari yapı, \%11.5'i kamu yapısı, \%5'i eğitim yapısı, \%9.7'i dini yapı, \%4'ü askeri yapı olduğu belirlenmiştir. Bu planlama ile konut ve eğitim yapıları azalmış, ticari, kamu, dini, askeri yapıları artmıştır. Ayrıca alana ticari-konut alanları eklenmiş̧ir (Şekil 6). Farklı alan kullanımlarına ilişkin görseller de Şekil 7. de verilmiştir.

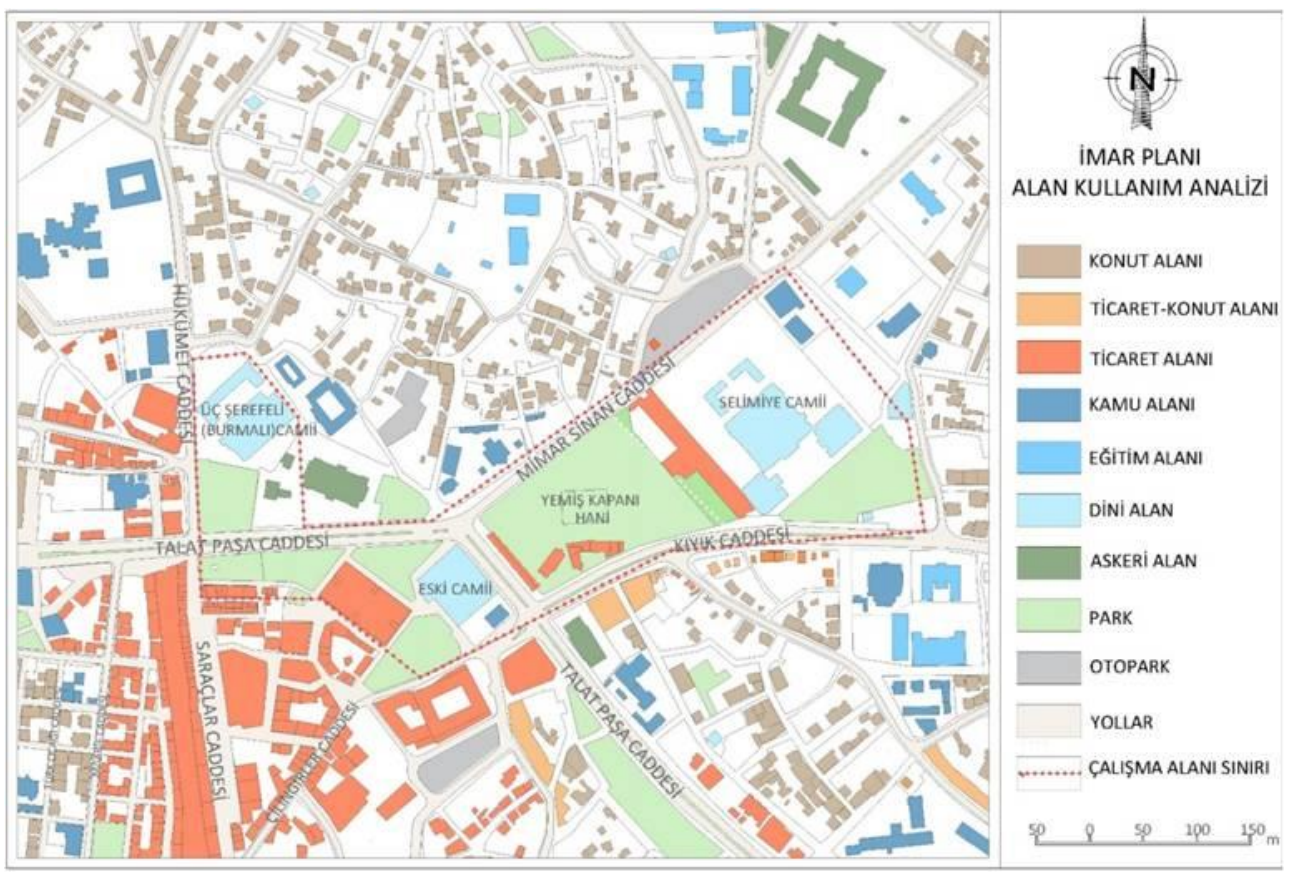

Şekil 6. Uygulama İmar planına göre alan kullanım analizi
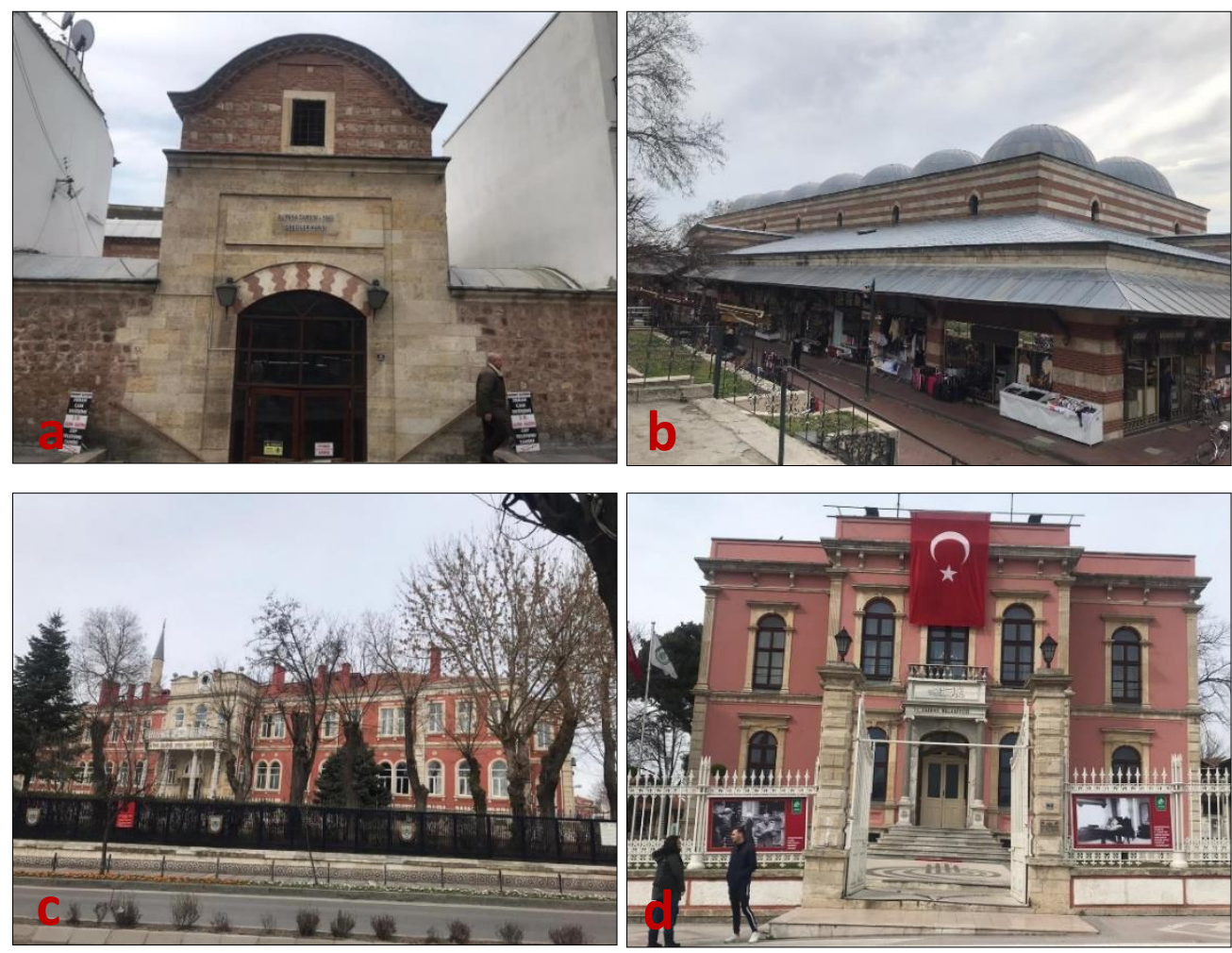

Şekil 7. a) Alipaşa Çarşısı (Ticaret alanı) b) Bedesten (Ticaret alanı) c) Tugay Komutanlığı (Askeri alan)

d) Belediye binası (Kamu alanı) 


\subsection{Açık- Yeşil Alan Durumuna İliş̧kin Bulgular}

Çalışma alanı çevresinde $38900 \mathrm{~m}^{2}$ 'lik yeşil alan bulunmaktadır. Alanın \%5.4'ünü oluşturan yeşil alanlar, çoğunlukla anıtsal yapıların ve ticaret alanlarının (kafe, restoran) bahçeleri olarak, oturma, dinlenme ve seyir amaçlı kullanımlar için ayrıldığı gözlemlenmiştir (Şekil 8, Şekil 9). Bu durum yeşil alanların daha etkin olarak kullanılmasının gerekliliğini ortaya çıkartmaktadır.

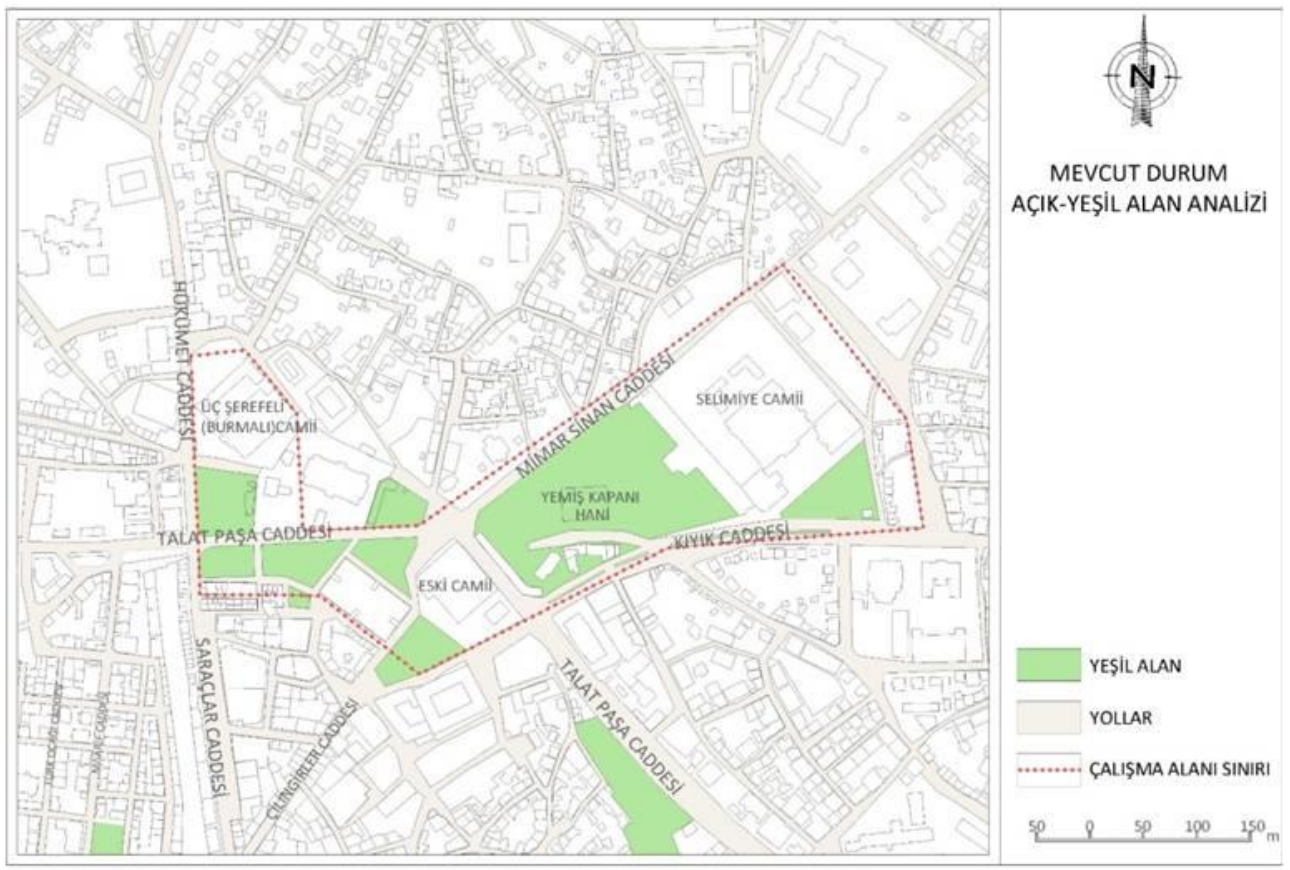

Şekil 8.Araştırma alanına ilişkin mevcut durum yeşil alan analizi
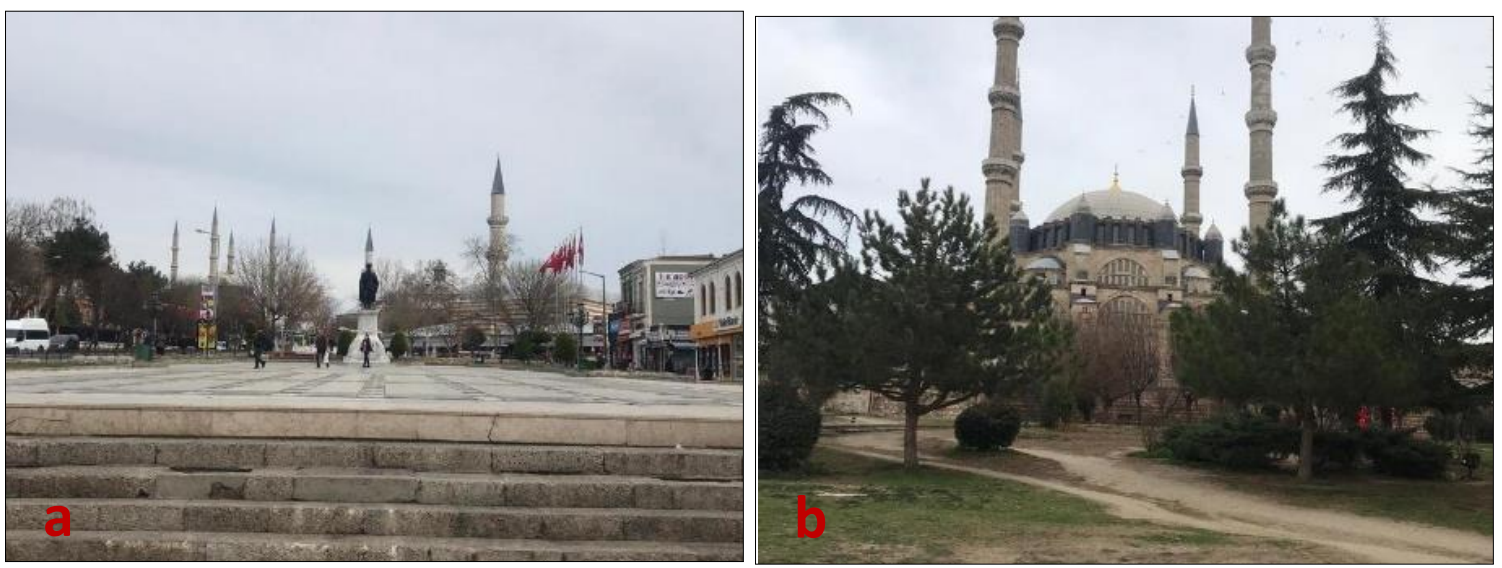

Şekil 9. a) Edirne meydanı b) Selimiye Camii önündeki açık-yeşil alan

Uygulama İmar Planına göre araştırma alanı ve çevresinde $49500 \mathrm{~m}^{2}$ yeşil alan planlanmıştır. Alanın \%6.9'unu kaplayan yeşil alanlar; mevcut yeşil alanların korunması ve imar planında yeni yeşil alanların eklenmesi ile oluşturulmuştur. Bu planlama ile özellikle alanın kuzey ve güney bölümlerinin bir kısmına yeni yeşil alanların eklenmesi ile yeşil alan miktarı artmıştır (Şekil 10). 


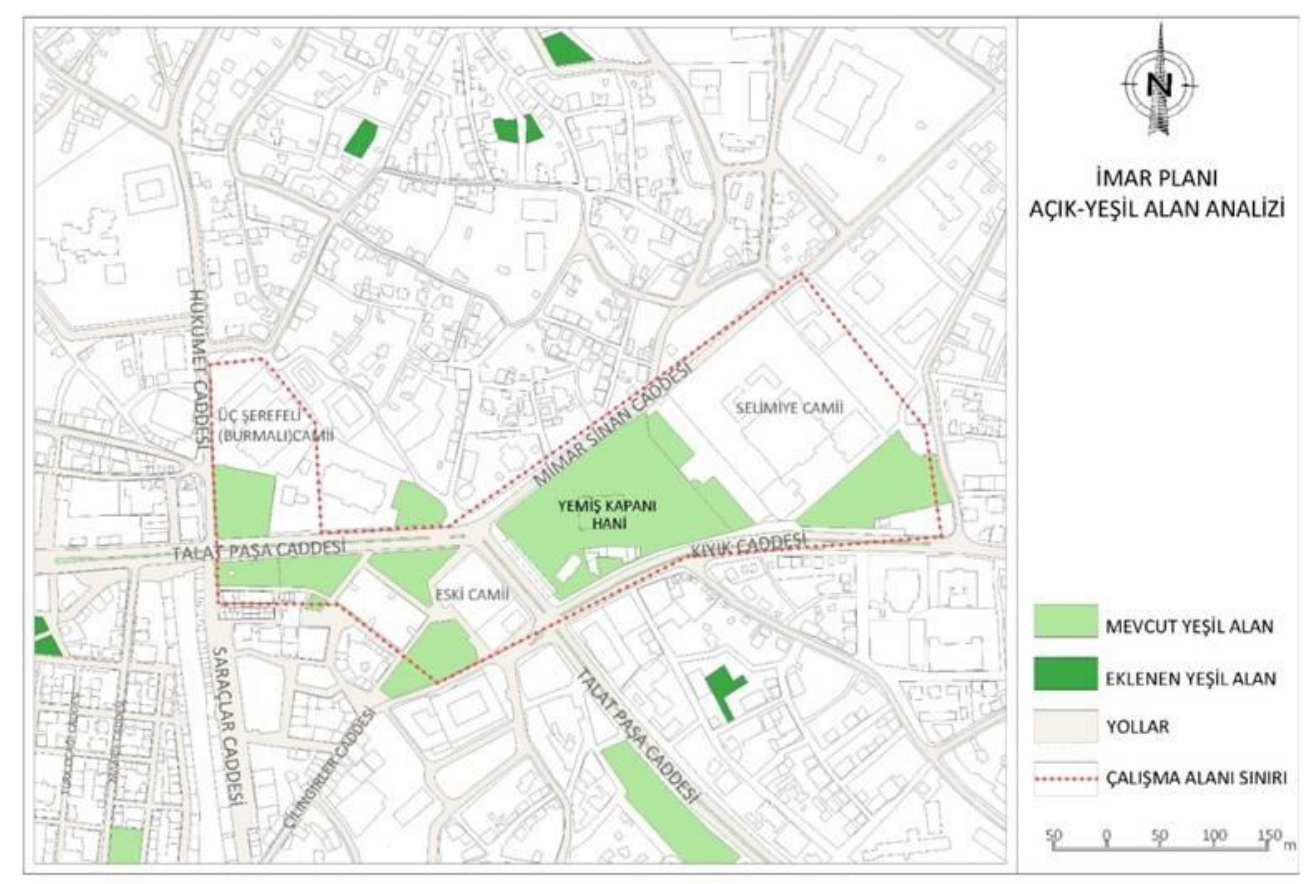

Şekil 10.Uygulama İmar Planına göre yeşil alan analizi

\subsection{Kütle-Boşluk Durumuna İlişkin Bulgular}

Çalışma alanı ve çevresinde kütle-boşluk durumu incelendiğinde; genel anlamda yapı ile boşluk alanı oranının dengeli olmadığı saptanmıştır (Şekil 11). Şekil 11 incelendiğinde; güney yönde bitişik ve sık yapıların, kuzey yönde ise dağınık ve az yoğunlukta yapıların olduğu gözlemlenmiştir. Ayrıca kent merkezinde, vistaların oluşturulacağı nitelikte açıklıkların fazla olduğu bir düzen gözlemlenmiştir. Bu durum araştırma alanının mekansal kalitesine olumlu etki yaratmaktadır.

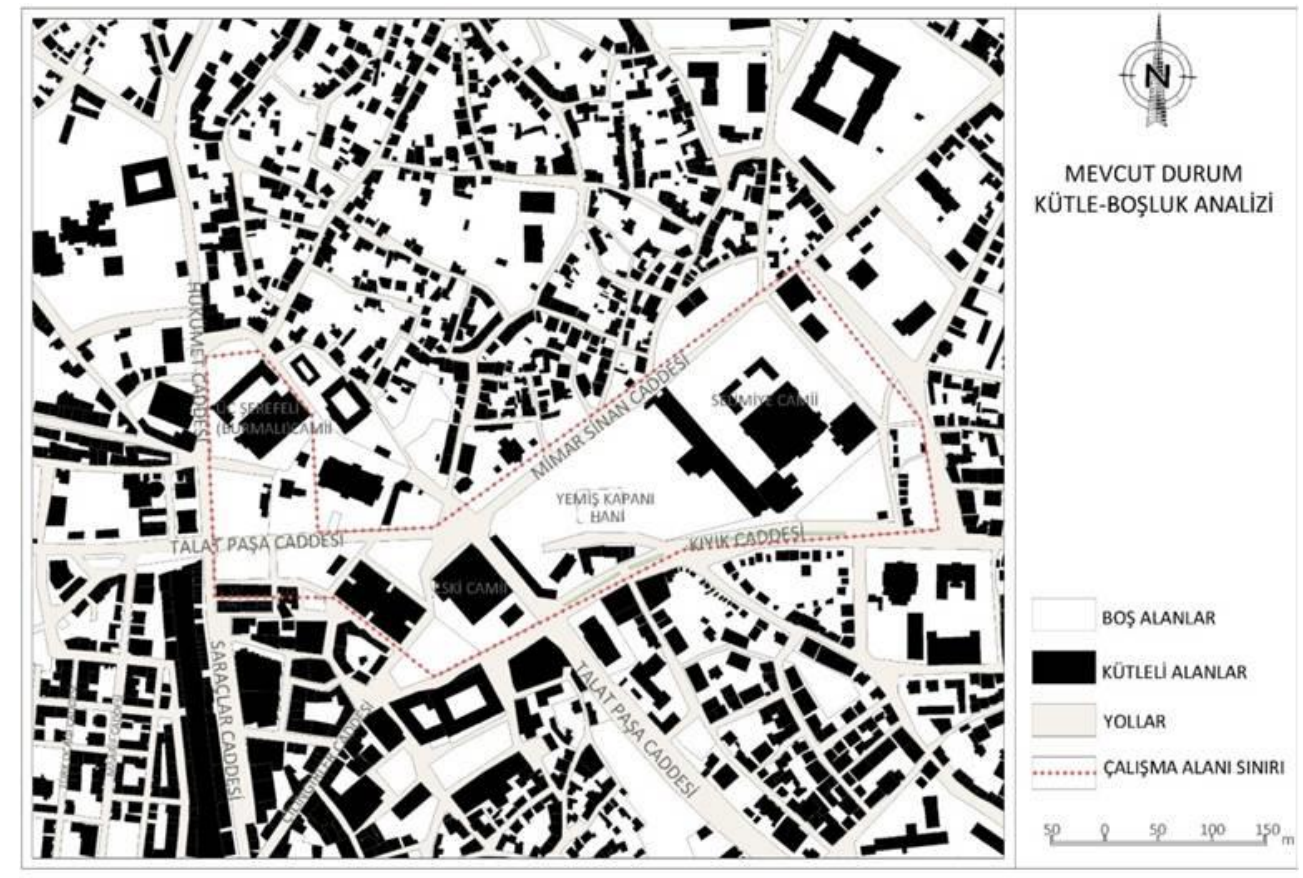

Şekil 11. Araştırma alanına ilişkin mevcut durum kütle-boşluk analizi 


\section{5. İnsan Ölçüsüne Uygunluk Durumuna İlişkin Bulgular}

Bu başlık çerçevesinde çalışma alanı ve yakın çevresine ilişkin kat yükseklik durumları saptanmıştır. Çalışma alanı çevresinde yapı yükseklerine bakıldığında yapıların; \%28.9'u 1 katlı, \%28'i 2 katlı, \%23.3'ü 3 katlı, \%8.2'si 4 katlı, \%4.6's1 5 katlı olduğu gözlemlenmiştir (Şekil 12).

Bir ve 2 katlı yapıların çoğunlukta olması Selimiye Camii, Eski Camii, Üç Şerefeli Camii, Makedonya Kulesi'nin oluşturduğu tarihi siluetin algılanmasını güçlendirirken, çevredeki pek çok noktadan görülebilmesine olanak sağlamaktadır. Bu durum araştırma alanının mekan kalitesine olumlu bir nitelik sağlamaktadır.

Uygulama İmar Planına göre çalışma alanı ve çevresinde yapı yüksekleri incelendiğinde ise; \%13.8'i 1 katlı, \%21.9’u 2 katlı, \%43.6'sı 3 katlı, \%11'i 4 katlı ve \%9.7'si dini yapı olduğu belirlenmiştir. Bu planlamada 3 katlı yapıların oranın artmasına karşın, v 5 katlı yapılara yer verilmediği görülmüştür (Şekil 13).

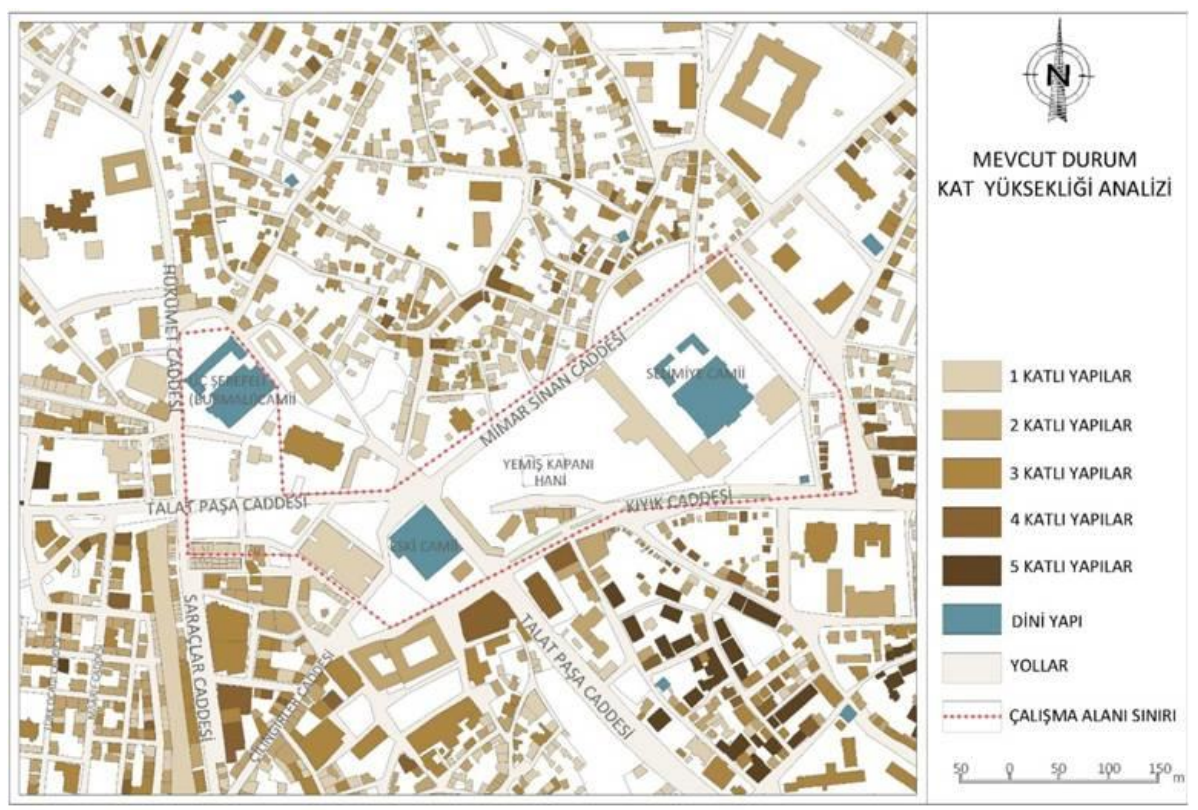

Şekil 12. Araştırma alanına ilişskin mevcut durum kat yüksekliği analizi

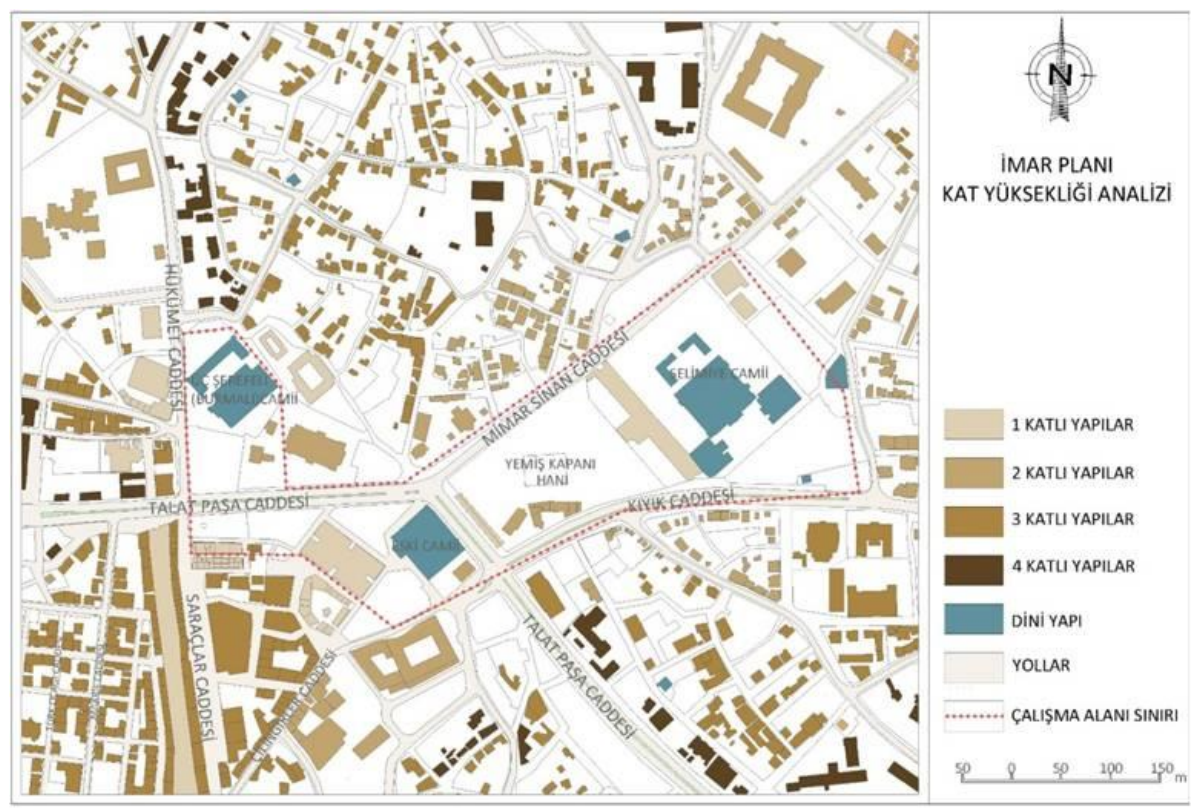

Şekil 13. Uygulama İmar planına göre kat yüksekliği analizi 


\subsection{Korunan Alanların Durumuna İlișkin Bulgular}

Alan üst ölçekten incelendiğinde, Kaleiçi semti, Selimiye Camii ve çevresi, Ayșekadın semti ile Kervansaray bölgesinin (yaklaşık 50 ha'lık alan) kentsel sit alanı sınırları içerisinde yer almaktadır. Bununla birlikte, Kaleiçi bölgesi (yaklaşık 18 ha'lık alan) 3. Derece Arkeolojik Sit Alanı ve bu alan içerisindeki sur duvarlarının günümüzde görülen kısımları da 1. Derece Arkeolojik Sit Alanı içerisinde yer almaktadır (Şekil 14).

Araştırma alanı ise; Kentsel Sit Alanı ve Koruma Amaçlı Uygulama İmar Planında belirlenen kentsel tasarım özel proje alanı kapsamında yer almaktadır.

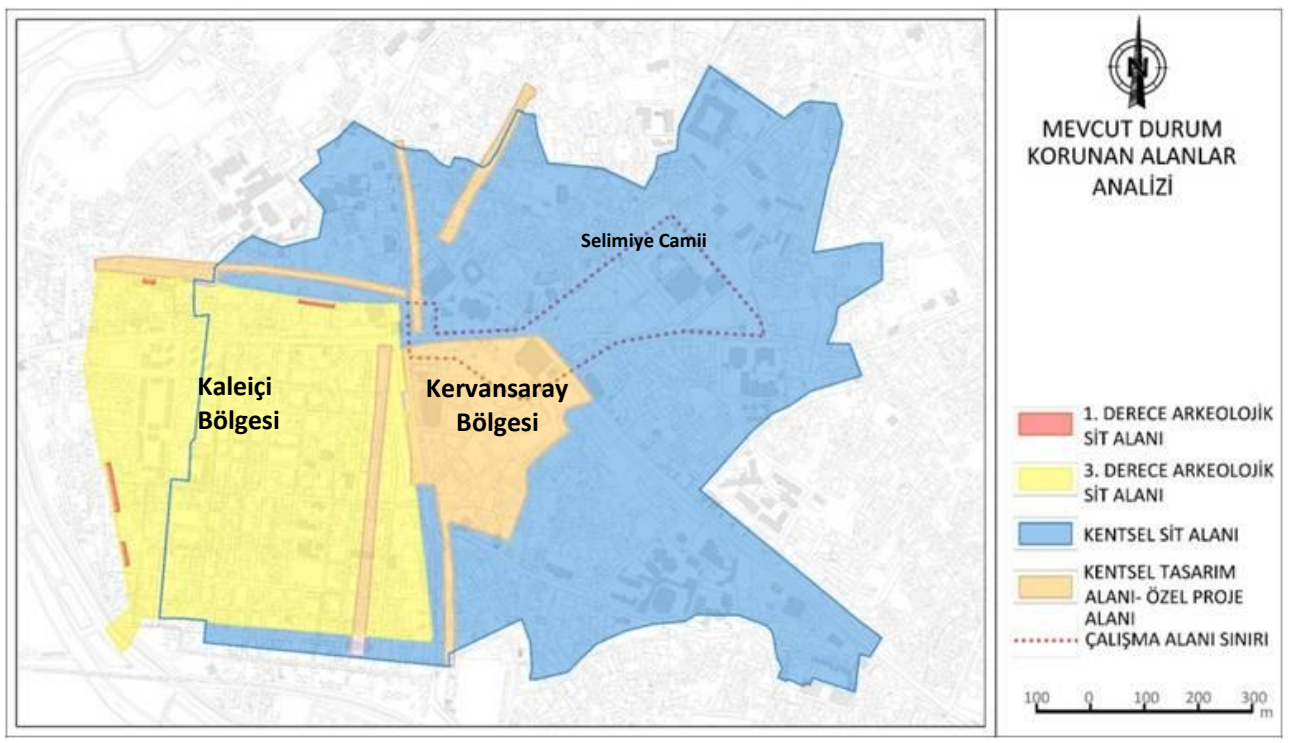

Şekil 14. Araştırma alanının korunan alanlar içerisindeki durum analizi

\subsection{Tescilli Yapı Durumuna İlişkin Bulgular}

Araştırma alanı ve çevresinde tescilli anıtsal yapılar ve sivil mimari yapılar bulunmaktadır. Kaleiçi bölgesinde ve kentin farklı bölgelerinde yer alan köşkler, konaklar ve özel dekore edilmiş ahşap evler günümüze kadar gelerek sivil mimari örneği oluşturmaktadır. Alan içerisindeki tescilli anıtsal yapılar; Selimiye Cami, Eski Camii, Üç Şerefeli Camii, Alipaşa Çarşısı, Kervansaray, Makedonya Kulesi, Deveci Hanı (Eski Cezaevi), Saatli Medrese olup, bu yapılar Land Mark noktaları oluşturmaktadır (Şekil 15, Şekil 16).
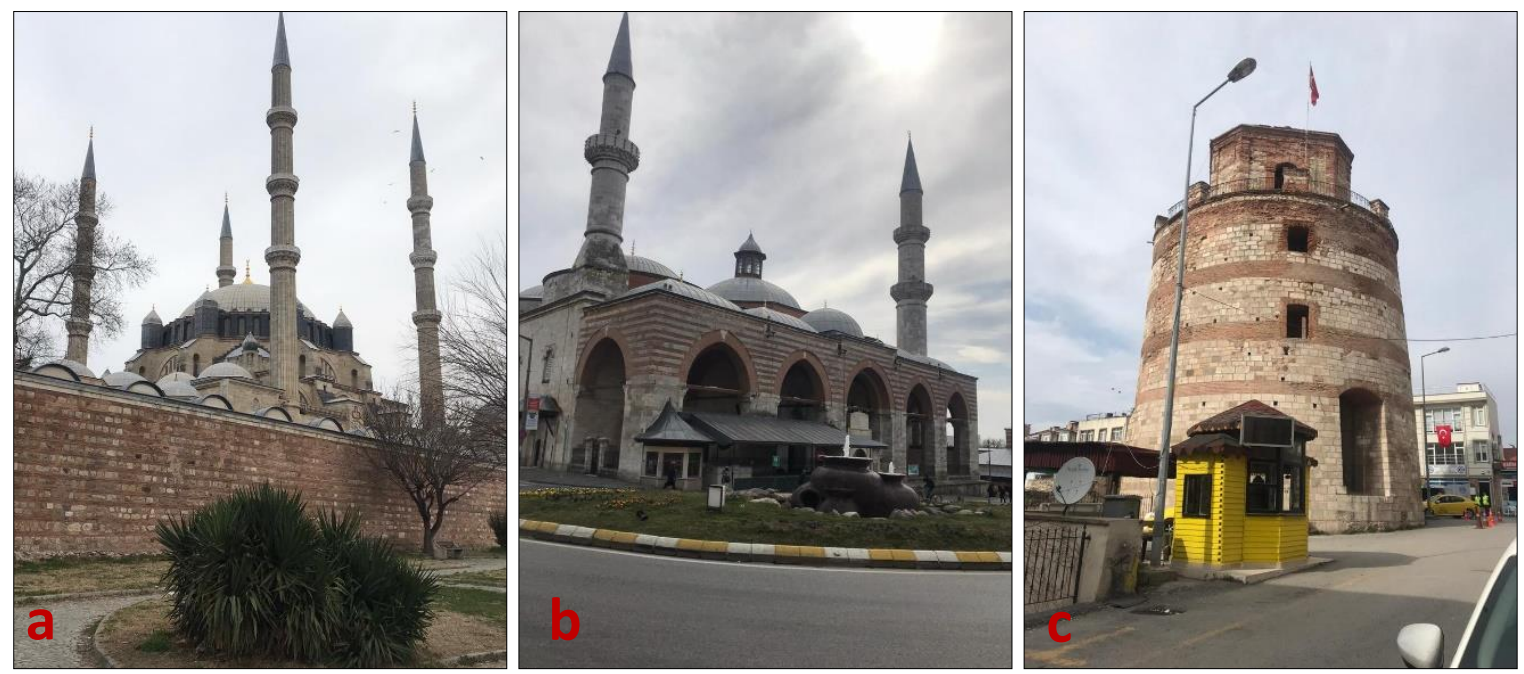

Şekil 15. a) Selimiye Camii b) Eski Camii c) Makedonya Saat Kulesi 


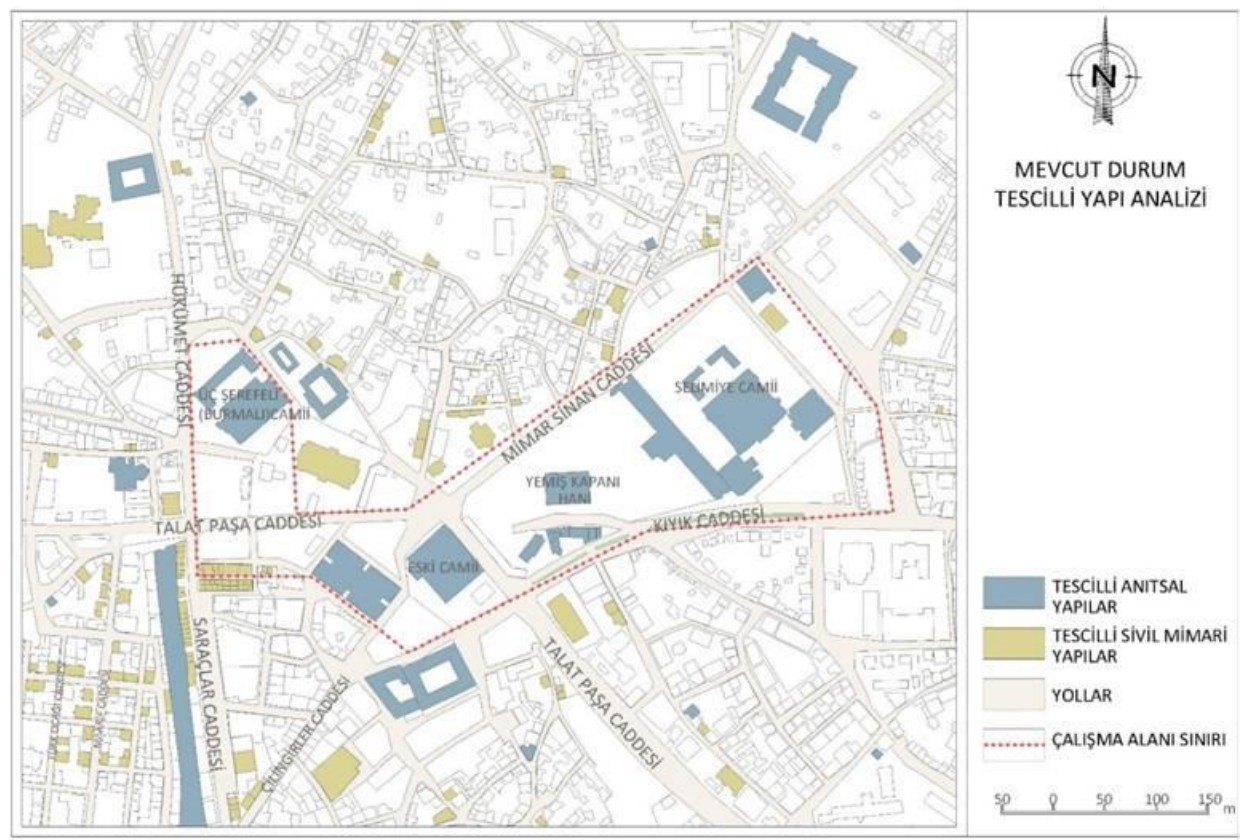

Şekil 16. Araştırma alanına ilişkin tescilli yapı analizi

\subsection{Kentsel İmgelere İlişkin Bulgular}

Bu başlık altında; kent imajında belirleyici rol oynayan, aynı zamanda, kentin algılana bilirliğini ve okunabilirliğini kuvvetlendiren öğelerden yararlanılmıştır. Bu kapsamda, Lynch (1960)'nin fiziksel unsurlardan yola çıkarak oluşturduğu, kentin imajını belirlemekte rol oynayan kentsel imge elemanları olan bağlantılar, bölgeler, sınırlar, nirengiler ve odaklar çerçevesinde araştırma alanı ve çevresine yönelik kentsel imaj analizi paftası oluşturulmuştur. Topçuoğlu ve ark. (2019); Tırnakçı ve Aklıbaşında (2018) ve Çelikyay (2017)'nin de belirttiği gibi Landmarklar; form, doku, renk, boyut gibi özellikleri nedeniyle çevrelerindeki öğelere nazaran daha çok ayırt edilen ve görsel algının oluşmasında belirleyicidirler. Bu kapsamda; yeşil alanlar bölgeleri, kavşaklar düğüm noktalarını, araç yolu olan Talat Paşa, Kıyık, Hükümet ve Mimar Sinan Caddeleri izleri oluşturmaktadır. Selimiye Camii, Selimiye Arastası, Fatih Sultan Mehmet heykeli, Eski Camii, Bedesten, Alipaşa Çarşısı, Makedonya kulesi, Taşhan, Üç Şerefeli Camii, Kirazlı Camii, Saray Hamamı ise kent kimliğini destekleyen odak yapıları (Land mark) oluşturmaktadır (Şekil 17).

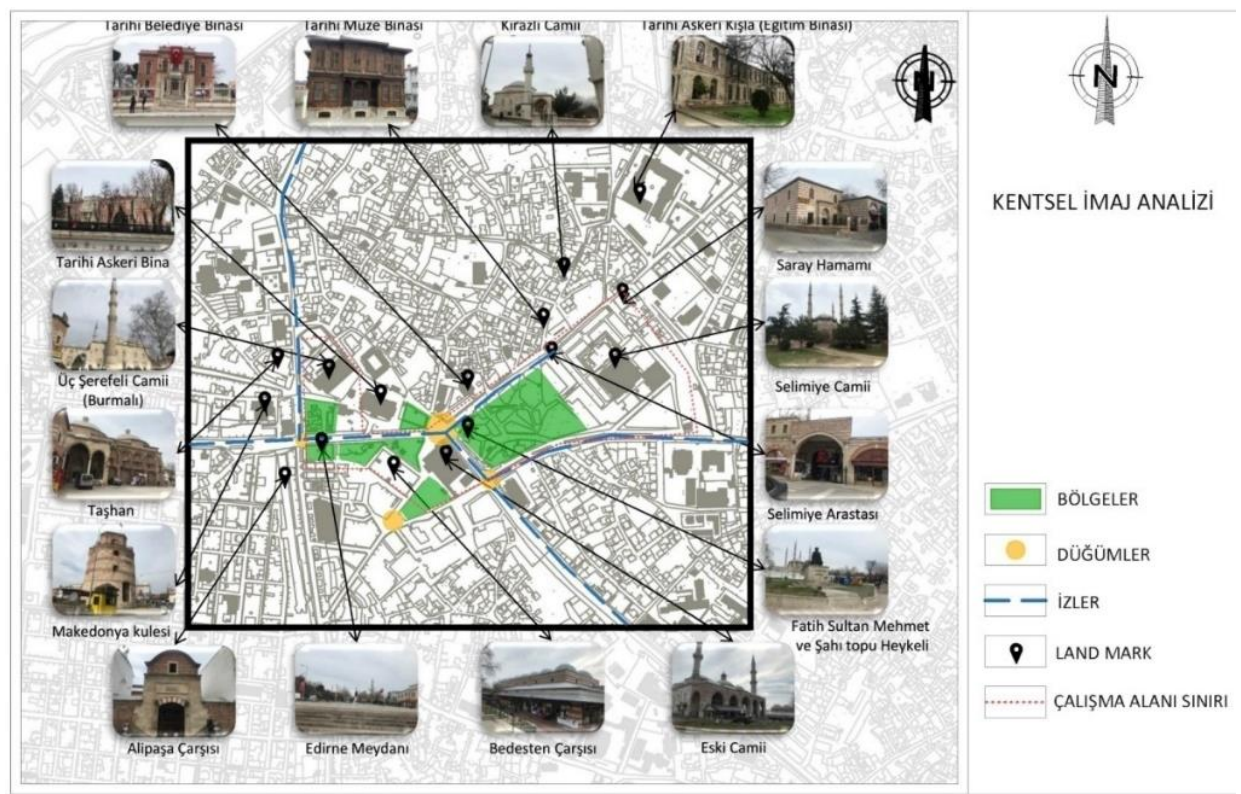

Şekil 17. Kentsel imaj analizi 


\section{9. Çalışma Alanının Zayıf ve Güçlü Yönlerine İlişkin Bulgular}

Yapılan analizler ve gözlemler sonucunda, Swot Analizi tekniği kullanılarak alanın güçlü ve zayıf yönleri ile firsat ve tehditleri belirlenmiştir. Bu doğrultuda; güçlü yönler olarak ön plana çıkan değerler; alanın kentin odak noktasında yer alması ile sahip olduğu anıtsal yapılar ve tarihi kimliği ile Kentsel Sit Alanı sınırları dahilinde bulunması, Selimiye Camii, Selimiye Arastası, Fatih Sultan Mehmet Heykeli, Eski Camii, Bedesten, Alipaşa Çarşısı, Makedonya Kulesi, Taşhan, Üç Şerefeli Camii, Kirazlı Camii, Saray Hamamı gibi Landmarkların alan içi ve yakın çevresi olması ile sosyal ve kültürel aktivitelere yönelik kullanım çeşitliliği olmuştur. Yeşil alanların, yaya alanlarının ve otoparkların da yetersiz olması da zayıf yönler olarak belirlenmiştir. Bununla birlikte, üst ölçek planlarda mekansal kalite ve insan odaklı yaklaşım kararlarının ön planda vurgulanması, Edirne kentinin tarihi miras ve sınır kenti potansiyeli firsatlar olarak değerlendirilirken, yine sınır kentinden kaynaklı ilginin yaratabileceği ve kentleşmenin oluşturabileceği olumsuz etkiler ve kentsel konfor anlayışının zaman içinde değişime uğrama olasılığı da tehditler olarak belirlenmiştir (Tablo 2).

Tablo 2. Alana İlişkin Swot Analizi

\begin{tabular}{|c|c|}
\hline Güçlü Yönler & Zayıf Yönler \\
\hline $\begin{array}{l}\text { - Kent merkezinde olması. } \\
\text { - } \quad \text { Landmark noktalarının yer alması. } \\
\text { - } \quad \text { Kentsel sit alanı kapsamında yer alması. } \\
\text { - } \quad \text { Yayaliaşistırılan tarinini ve ticaret odağ Saraç } \\
\quad \text { Caddesi ve Alipaşa Çarşına yakın olması. } \\
\text { - Alan ve çevresinde kentin imge noktaları } \\
\text { düşünülerek, yapıların kat yüksekliklerinin } \\
\text { insan ölçeğinin çok üstünde tutulmaması. } \\
\text { - Alan ve çevresinde otoparkların bulunması. }\end{array}$ & $\begin{array}{l}\text { - Yaya alanlarının bakımsız ve düzensiz } \\
\text { olması. } \\
\text { - Kentin görüntüsünü engelleyen kaçak yapı } \\
\text { ve bitkilendirmelerin bulunması. } \\
\text { - Yolların genişliklerinin standart ölçüde } \\
\text { olmaması. } \\
\text { - Yaya geçitlerinin az ve kontrolsüz olması. } \\
\text { - Belirli günler ve özel günlerde otopark } \\
\text { sorununun olması. } \\
\text { - Alan ve çevresindeki yollara araç park } \\
\text { ediliyor olması. }\end{array}$ \\
\hline Firsatlar & Tehditler \\
\hline $\begin{array}{l}\text { - Üst ölçek plan kararlarında mekansal kalite } \\
\text { - } \text { Kaklaşımına önem verilmesi } \\
\text { Kalkınma planlarında insan odaklı yaklaşım } \\
\text { anlayışının önemsenmesi } \\
\text { - Edirne'nin tarihi miras potansiyeli } \\
\text { - Yerli ve yabancı turistlerin ilgi odağı } \\
\text { olması } \\
\text { - Sinır kenti olma potansiyeli }\end{array}$ & $\begin{array}{l}\text { - Sınır kenti olmasından dolayı yoğun ilginin } \\
\text { yaratacağı olumsuzluklar } \\
\text { - Kentleşmenin yaratacağı olumsuz etkiler } \\
\text { - Kentsel konfor anlayışının zaman içinde } \\
\text { değişim gösterme olasılığı }\end{array}$ \\
\hline
\end{tabular}

\section{SONUÇ}

Yapılan analizlerden elde edilen bulgular kapsamında; kentsel mekan kalitesinin güçlendirilmesi çerçevesinde tarihi kent merkezinin çevresi ile bütünlüğünün sağlanması ve kentin kültürel kimliğinin sürdürülebilmesi adına çözüm odaklı uygulamaya yönelik öneriler yapılmış ve tasarım kararları gerçekleştirilmiştir (Şekil 18). Selimiye Camii ve çevresi için öneriler ulaşım, açık-yeşil alan, malzeme-renk ve doku olmak üzere üç başlık altında toplanmıştır.

\subsection{Ulaşım Durumuna Ilişsin Öneriler}

Bulgular bölümünde ulaşım durumuna ilişkin saptanan sorunlar kapsamında kentsel mekan kalitesinin iyileştirilmesine yönelik tasarım kararları geliştirilmiştir.

- Yayaların Selimiye Camiine ulaşımında yaşadığı sorunlar (Kaldırımların yetersiz olması, trafik yoğunluğu) göz önüne alınarak (Şekil 19a); Mimar Sinan Caddesi'nin Talat Paşa Caddesi tarafindan ilk 200 m'sinin paylaşımlı yaya öncelikli (08.00-22.00 saatleri arasında) olarak kullanımı sağlanmalıdır.

- Yayaların Talat Paşa Caddesinde yaya geçitlerinde yaşadıkları sorunlar (yaya geçidinin olmaması ve yaya geçidinin dar olması) göz önüne alınarak (Şekil 19b-c), yaya geçitlerinin genişletilmeli ve yenilerinin eklenmesi sağlanmalıdır.

- Alanda yayalaştırma sonucunda oluşacak otopark sorunu için mevcutta kullanılan otoparkın (20 araç) tekrar düzenlenmesi yapılmalı ve alanın yakın çevresinde otopark alanları oluşturulmalıdır (Şekil 20). 


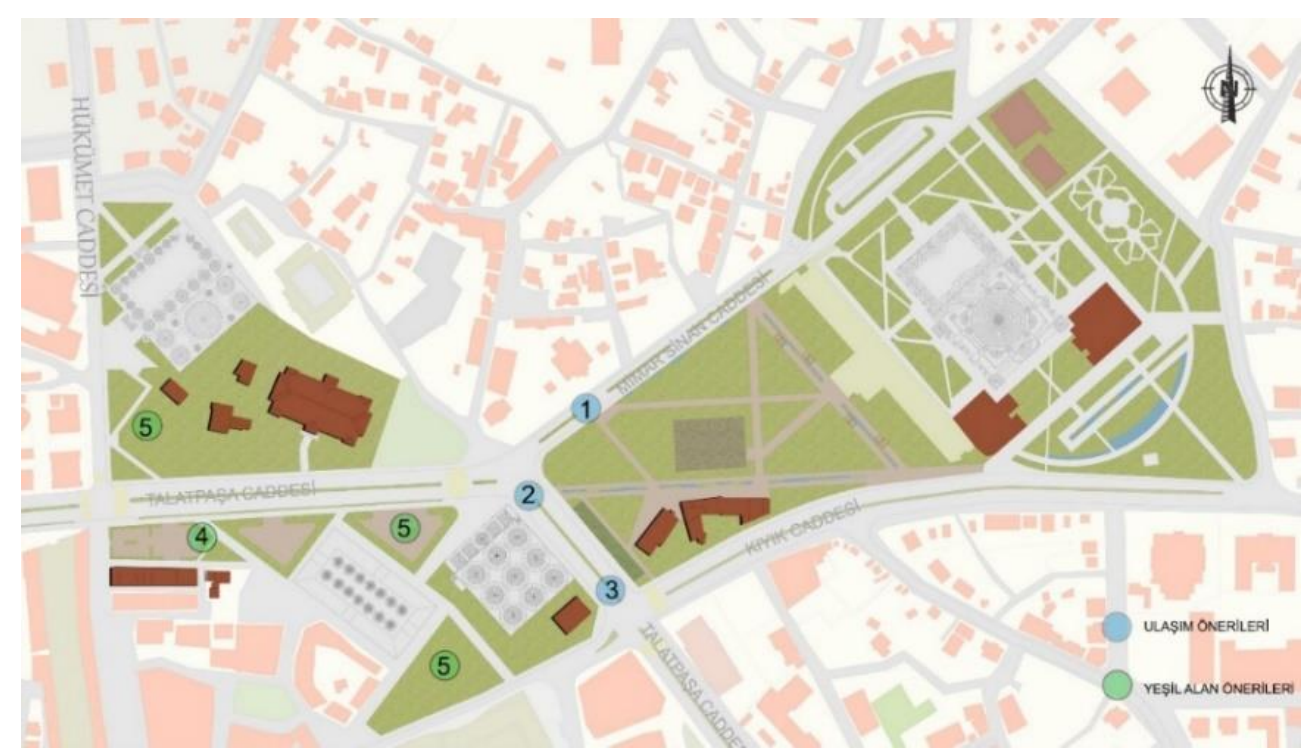

Şekil 18. Selimiye Camii ve çevresi öneri planı
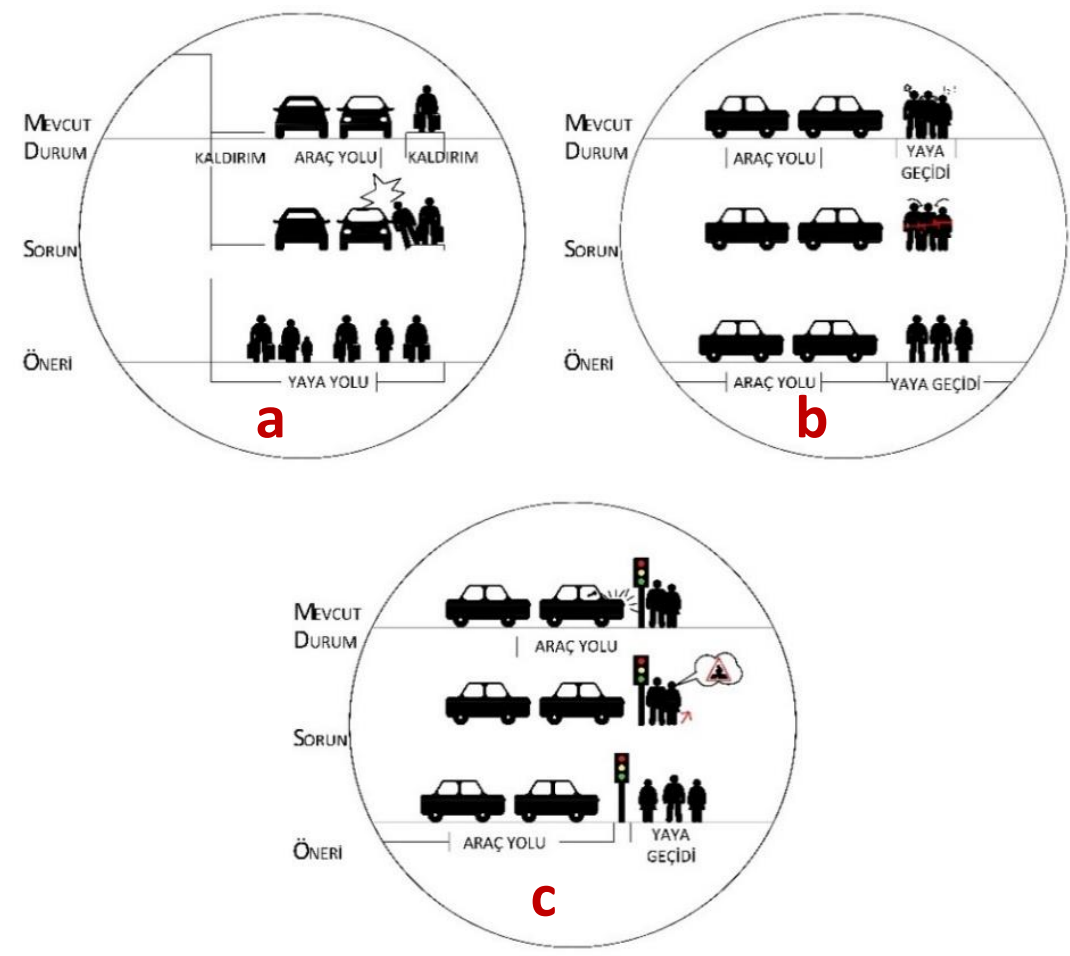

Şekil 19. a) 1 numaralı ulaşım sorunu ve önerisi b) 2 numaralı ulaşım sorunu ve önerisi c) 3 numaralı ulaşım sorunu ve önerisi 


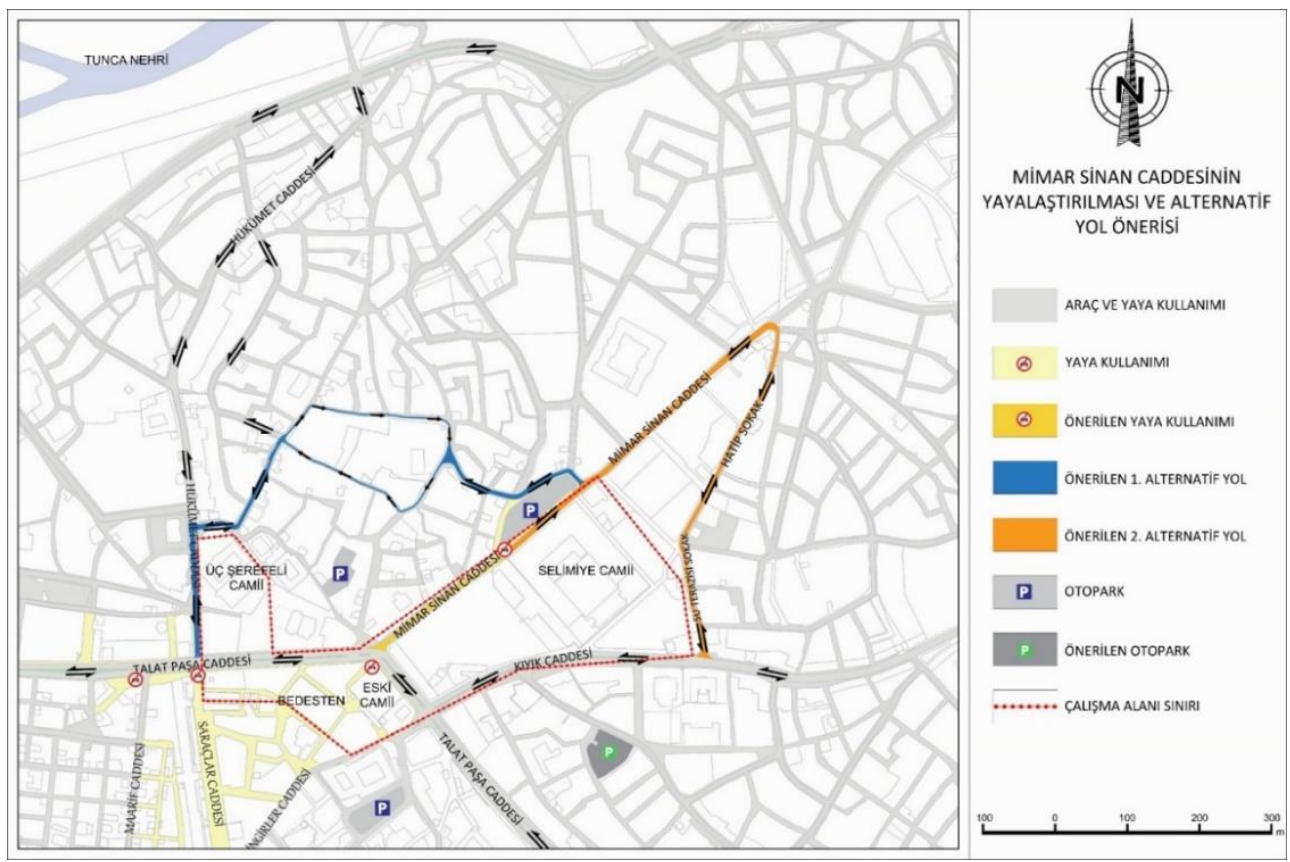

Şekil 20. Araştırma alanına ilişkin alternatif yol ve otopark önerisi

\subsection{Yeșil Alan Önerileri}

Bulgular bölümünde yeşil alanlara yönelik saptanan sorunlar kapsamında kentsel mekan kalitesinin iyileştirilmesine yönelik tasarım kararları geliştirilmiştir.

- Kamusal yeşil alanlarda yer alan ticari alanların (kafeterya, büfe vb.), açık-yeşil alanların büyük bir bölümünü kullanması sorunu göz önünde bulundurularak (Şekil 21a); ticaret alanlarının yerleri ve sınırları belirlenmeli, diğer alanların halka açık dinlenme olarak tasarlanmalıdır.

- Selimiye Camii’nin önündeki yeşil alanda yer alan Yemiş Kapanı Hanı korunarak dinlenme alanı olarak tasarımı yapılmalıdır.

- Meydan kullanımı için yetersiz olan (Şekil 21b) meydan genişletilmeli, törenler dışında dinlenme alanı olacak şekilde tasarlanmalıdır.

- Selimiye Camii ve çevresinde ticari alanlar oluşturularak, Edirne tarihini ve kültürünün yansıtan özgün ürünlerin satıldığı mekanlar olarak işlevlendirilmelidir.
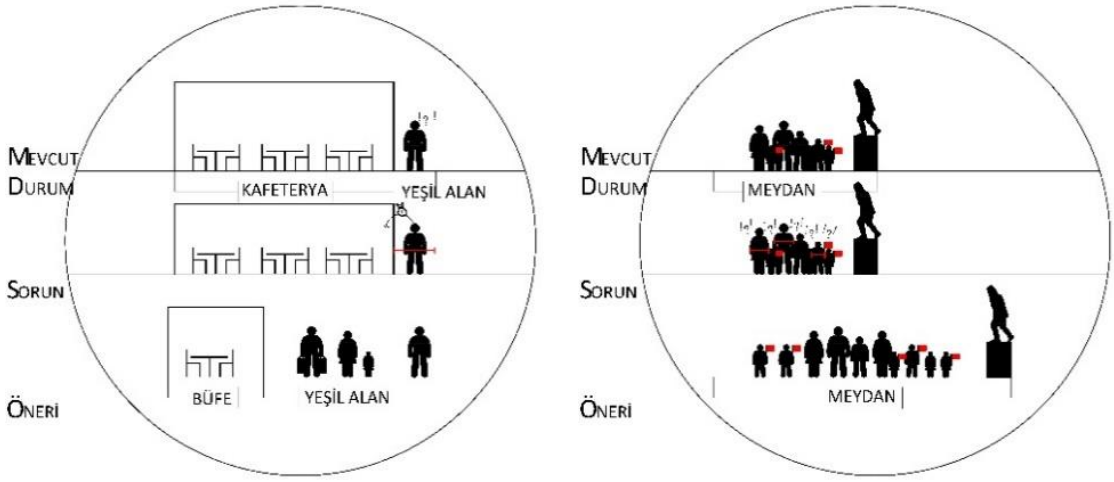

Şekil 21. a) 5 numaralı yeşil alan sorun ve önerisi b) 4 numaralı yeşil alan sorun ve önerisi

\subsection{Malzeme, Renk ve Doku Önerileri}

Araştırma alanını oluşturan kentsel mekanın görsel yönden kalitesini güçlendirecek malzeme, renk ve dokuya ilişkin tasarım kararları geliştirilmiştir. 
- Selimiye, Eski ve Üç Şerefeli Camii'nin çevresindeki yapıların cephelerinde dil birliğinin oluşturabilmesi için tarihi dokuya uygun renk ve malzeme kullanılmalıdır.

- Ticari yapılarda imajı güçlendirme amaçlı tek tip tabela kullanılmalıdır.

- Yaya yolları ve mekanların da ulaşımı engellemeyecek ve doğal malzemeler kullanmalıdır.

- Kullanıcının ihtiyaçlarını karşılayacak tarihi dokuya uygun çeşitli oturma birimi, aydınlatma elemanı, çöp kutusu kullanılmalıdır.

Araştırma alanına yönelik geliştirilen tasarım kararları çerçevesinde; Selimiye Camii ve çevresinde ziyaretçilerin ihtiyaçlarına yönelik çekici, güvenli ve çeşitlilik sağlayan alanlar yaratmak adına; camii önündeki yeşil alan (Yemiş Kapanı Hanı'nın bulunduğu alan) düzenlenip, ticaret alanı birleștirilerek yöresel ürünlerin satılabileceği/ sergilenebileceği alanlar oluşturulmuştur (Şekil 22).

Trafik sorunu yaşanan, Mimar Sinan Caddesi yayalaştırılmış ve yol kenarlarına dinlenme alanları tasarlanmıştır (Şekil 23). Yayalaştırma sonucu oluşacak otopark sorunu için mevcutta kullanılan otopark (20 araç) yeniden düzenlenmiştir (Şekil 24).

Edirne Meydanı olarak bilinen törenlerin yapıldığı alanın ihtiyaçları karşılamağı ve kullanımın yetersiz olması göz önüne alınarak tekrardan düzenmiş ve tören dışında kullanımlar için dinlenme alanı olarak kullanılması için düzenlemeler yapılmıştır (Şekil 25).
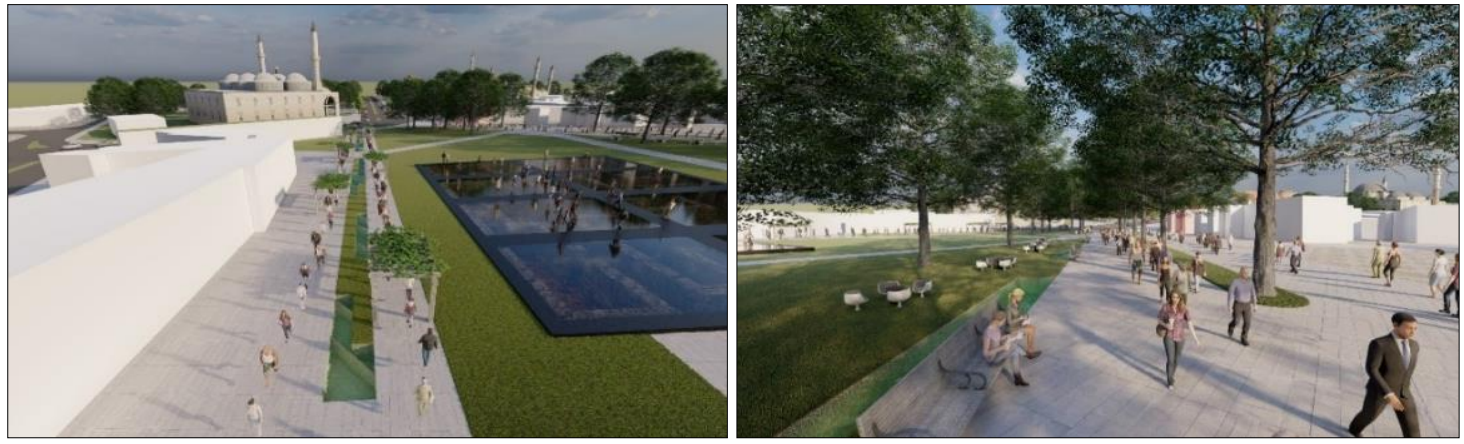

Şekil 22. Yeşil alan, Yemiş Kapanı Hanı ve ticaret alanı Şekil 23. Yayalaştırılan Mimar Sinan Caddesi

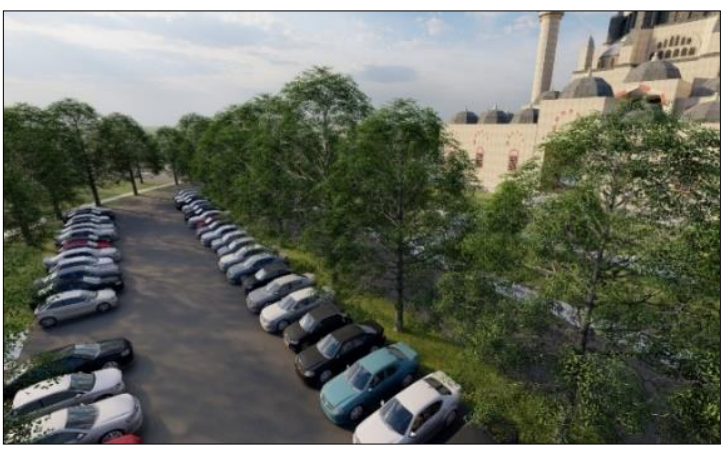

Şekil24. Düzenlenmiş otopark

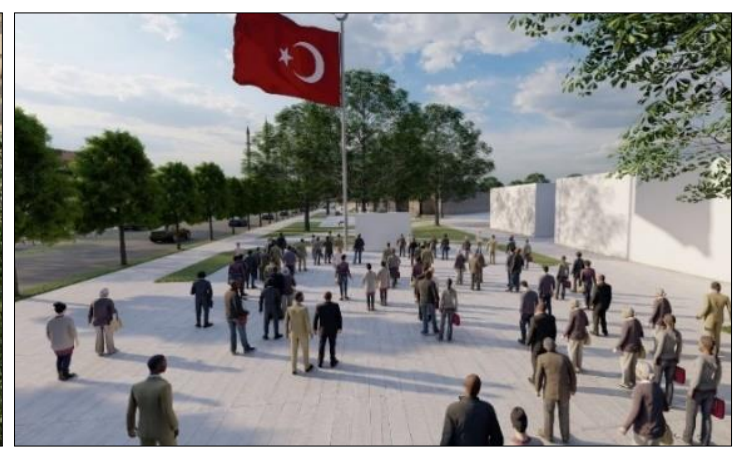

Şekil 25. Tören alanı ve dinlenme alanı

Bu çalışmada Edirne Selimiye Camii ve çevresi konfor ve imaj odaklı olarak fiziksel mekan kalitesi açısından değerlendirilmiş ve çeşitli tasarım kararları geliştirilmiştir. Çalışmadan elde edilen sonuçlar, özellikle kentsel alanlarda mekan kalitesinin güçlendirilmesi gerekliliğine dikkat çekerek, bu anlamda İnceoğlu, 2007; İnceoğlu ve Aytuğ, 2009; Çınar Altınçekiç ve ark., 2014; Uzgören ve Erdönmez, 2017; Acarlı ve ark. 2018; Akbaş ve Kiper, 2020; Tırnakçı, 2020'in yapmış oldukları çalışmaların sonuçları da destekler niteliktedir. Bu çalışmada, örnek olarak seçilen alan, Edirne'nin odağında yer alan, kentin ana karakterinin oluşumunda etken olan aynı zamanda kullanıcı yoğunluğunun fazla olduğu bir konumdadır. Aynı zamanda sahip olduğu anıtsal, tescilli sivil mimari yapıları ve ticaret alanları ile; Edirne'nin geçmişi ile bugünü arasında bir köprü görevini görmektedir. Böylelikle seçilen kentsel mekana ilişkin kaliteye ilişkin tasarım kararlarının geliştirildiği bu çalışmanın konusu oldukça önemlidir. Bu çalışmanın devamında, fiziksel mekan kalitesi ile kullanıcıların da istek ve beklentilerinin dikkate alındığı çalışmaların yapılmasında yarar vardır. 


\section{Etik Standart ile Uyumluluk}

Çıkar Çatışması: Yazarlar herhangi bir çıkar çatışmasının olmadığını beyan eder.

Etik Kurul İzni: Bu çalışma için etik kurul iznine gerek yoktur.

Finansal Destek: Yoktur.

Teşekkür: Yoktur.

\section{KAYNAKLAR}

Acarlı, B., Kiper, T., Korkut, A. (2018). Kent meydanlarının fiziksel mekan kalitesi: İstanbul Taksim Meydanı ve yakın çevre. Kent Akademisi, 11 (33), 29-41.

Akbaş, C., Kiper, T. (2020). Tekirdağ ili Muratlı İlçesi 100 yıl Caddesi’nin çevre imajı ve kent estetiği açısından incelenmesi. Artium, 8 (1), 30-43.

Anonim, (2020a). Merkez İlçe. Edirne İl Kültür ve Turizm Müdürlüğü, https://edirne.ktb.gov.tr/TR-76438/merkezilcesi.html (erişim tarihi, 16.04.2020).

Anonim, (2020b). Edirne ilimizin coğrafi yapısı ve iklimi. https://www.ilimiz.net/detay/22/176/edirne-ili-cografiyapisi-ve-iklimi.html(erişim tarihi, 16.04.2020).

Baysal, A.F. (2013). Edirne Osmanlı Erken Dönem Camileri kalem işi örnekleri ve analizleri (Doktora tezi). Necmettin Erbakan Üniversitesi Sosyal Bilimler Enstitüsü, Konya.

Birol, G. (2007). Bir kentin kimliği ve kervansaray oteli üzerine bir değerlendirme. Arkitekt Dergisi, 514, 46-54.

Çelikyay, H.S. (2017). Kamusal alanların mekansal organizasyonu. Çelikyay, H.S. Editör, Kent imgelerinin kamusal alanı tariflemedeki rolü (ss. 21). Bartın Üniversitesi Yayınları No:30, Fen Bilimleri Enstitüsü Yay. No:1.

Edirne Kültür ve Tabiat Varlıklarını Koruma Müdürlügü̈ Arşivi (2019). Sözlü Görüşme ve veri temini.

Erdoğan, E. (2006). Çevre ve kent estetiği. Bartın Orman Fakültesi Dergisi, 8(9), 68-77.

Erdoğan, E., Kuter, N. (2010). Edirne kenti kültür varlıklarının kent estetiği açısından değerlendirilmesi. Tekirdağ Ziraat Fakültesi Dergisi, 7(3), 137-145.

Erdönmez, E., Çelik, F. (2016). Kentsel mekanda kamusal alan ilişkileri. Türkiye Bilimler Akademisi Kültür Envanteri Dergisi, 14/2016, 145-163.

Ersoy, B. (2018). Edirne Yemiş Kapanı ve restitüsyon önerisi. Sanat Tarihi Dergisi, 27(1), 119-133.

Erten, S. (2016). Bir kentsel tasarım yarışmasının süreç analizi: Edirne/ Selimiye örneği ve tarihi merkezde araç yolu tartışması. Planlama Dergisi, 26(1), 20-31.

Karakaya, B. (2013). Kentsel peyzaj-sürdürülebilirlik-kent silueti: Edirne Tarihi Çekirdeği (Yüksek Lisans tezi), Trakya Üniversitesi Fen Bilimleri Enstitüsü, Edirne.

Karakaya, B.A., Ertin, D.G., Özyavuz, M. (2016). Kent kimliğinin Edirne Kaleiçi yerleşim alanı özelinde değerlendirilmesi. 4. Uluslararası Kentsel ve Çevresel Sorunlar ve Politikalar Kongresi, İstanbul.

Kaya, E. (2007). Kent araştırmaları merkezi ve kentsel yaşam kalitesi. Yerel Siyaset, 24, 35-36.

Kaypak, Ş. (2010). Antakya'nın kent kimliği açısından irdelenmesi. Mustafa Kemal Üniversitesi Sosyal Bilimler Enstitüsü Dergisi, 7(14), 373-392. 
Koçan, N. (2016). Kuzguncuk (Üsküdar) tarihi doku koruma ve yayalaştırma. Uluslararası Kültürel ve Sosyal Araştırmalar Dergisi, 2(1), 125-134.

Koçan, N. (2016). Kültürel miras ve koruma bağlamında Uşak tarihi kent merkezi yayalaştırma projesi. Uluslararası Kültürel ve Sosyal Araştırmalar Dergisi, 2(1),117-124.

Korkut, A., Kiper, T., Mısırlı, N., Akliman, S. (2019). Kentsel dönüşümün kent kimliğine etkileri, 6. Uluslararası Multidisipliner Çalışmaları Kongresi Tam Metin Bildiri Kitabı, 175-187, Gaziantep.

Madden, K. (2001). How toTurn a Place Around, A Handbook for Creating Success ful Public Spaces. Project for Public Spaces, edited by: Andrew Schwartez.

Mısırlı, N., Kiper, T., Korkut, A. (2019). Doğal ve kültürel kent kimliklerinin belirlenmesi: Edirne ili Karaağaç Mahallesi örneği. Bartın Orman Fakültesi Dergisi, 21(1), 52-65.

Oğurlu, İ. (2014). Çevre- kent imaj1- kent kimliği- kent kültürü etkileşimlerine bir bakış. İstanbul Ticaret Üniversitesi Fen Bilimleri Dergisi, 7(14), 373-392.

Şahin, E., Dostoğlu, N. (2007). Kentsel mekan tasarımında doğal verilerin kullanımı. Uludă̆ Üniversitesi Mühendislik-Mimarlık Fakültesi Dergisi, 12(1): 29-40.

Tırnakçı, A. (2020). Kentsel peyzaj tasarımı açısından tarihi Kayseri kent meydanının (Cumhuriyet Meydanının) irdelenmesi, Turkish Journal of Forest Science, 4(2), 314-332.

Tırnakçı, A., Aklıbaşında, M. (2018). Tarihi çevrelerde kentsel peyzaj tasarımın Kayseri Mimar Sinan Parkı örneğinde incelenmesi. Erciyes Üniversitesi Fen Bilimleri Enstitüsü Dergisi, 34(3):1-16.

Topçuoğlu, S., Kiper, T., Korkut, A., Akliman, S. (2019). Kırklareli ili Vize İlçesi örneğinde kent kimliğinin irdelenmesi. 6. Uluslararası Multidisipliner Çalışmaları Kongresi Tam Metin Bildiri Kitabı, 165-173s, Gaziantep.

Usal, A. (2006). Edirne tarihi ve kültürü. Edirne Vergi Dairesi.

Uzgören, G., Erdönmez, M.E. (2017). Kamusal açık alanlarda mekan kalitesi ve kentsel mekan aktiviteleri ilişkisi üzerine karşılaştırmalı bir inceleme. Megaron, 12(1), 41-56.

Van der Voort, T.J.M., Van Wegen, H.B.R., (2005). Architecture in use: an introduction to the programming, design andevalution of buildings. Architectural Press, Netherlands. 